\title{
Properties of Appropriately and Inappropriately Expressed Sodium Channels in Squid Giant Axon and Its Somata
}

\author{
Wm. F. Gilly and Tom Brismara \\ Hopkins Marine Station, Stanford University, Pacific Grove, California 93950
}

\begin{abstract}
Neurons that form the giant axons in squid by axonal fusion in the stellate ganglion are inexcitable and do not express functional voltage-controlled sodium $(\mathrm{Na})$ channels in their somata in vivo. These cells do express $\mathrm{Na}$ channels in the soma membrane in vitro, however, provided they have been axotomized. We describe here voltage-clamp experiments on the isolated cell bodies maintained in primary culture and on acutely isolated giant axons designed to compare the functional properties of the $\mathrm{Na}$ channels expressed inappropriately in the soma with those of channels expressed normally in the axon. Approximately $85 \%$ of $\mathrm{Na}$ channels in the soma are essentially indistinguishable from those in the giant axon with regard to gating properties and sensitivity to tetrodotoxin or saxitoxin. Thus, the isolated soma is capable of processing $\mathrm{Na}$ channels to a state of apparent functional perfection. In addition to these normal $\mathrm{Na}$ channels, another type is regularly expressed in the cultured somata. This second type lacks inactivation and is preferentially sensitive to block by cadmium ions, but is otherwise indistinguishable from the more prevalent normal type of channels.
\end{abstract}

Voltage-controlled sodium ( $\mathrm{Na}$ ) channels are an important determinant of neuronal function. Their exact functional properties, e.g., high voltage sensitivity and rapid activation/inactivation kinetics, and proper spatial localization, e.g., in axons and axon hillocks (Wollner and Catterall, 1986), are critical for a neuron to carry out its most basic task of impulse transmission. Like other membrane proteins, $\mathrm{Na}$ channels are not permanent features of an unchanging landscape, but the cellular regulation of the functional and distributional properties of a neuron's complement of $\mathrm{Na}$ channels has not yet been extensively characterized. Such regulation clearly operates both naturally and under many conditions in vitro (Schmidt et al., 1985; MacDermott and Westbrook, 1986; Rudy et al., 1987; Hugucnard et al., 1988; Mandel et al., 1988), and the potential control mechanisms are manifold.

Na channel subtypes have been physiologically and/or biochemically identified in many sources, in some cases single cells (see Barchi, 1987, 1988). Molecular identification and definition

\footnotetext{
Received June 27, 1988; revised Sept. 12, 1988; accepted Sept. 16, 1988.

We are grateful to Dr. Clay Armstrong for valuable collaboration, support, and laboratory space during the experiments on giant axons (1983-1985). Work on GFL cells was supported by Whitehall Foundation Grant J86-110 and National Institutes of Health Grant NS-17510 to W.F.G., and a Swedish-American Foundation award to T.B.

Correspondence should be addressed to Wm. F. Gilly at the above address.

a Present address: Department of Clinical Neurophysiology, Karolinska Hospital, Stockholm, Sweden.

Copyright (c) 1989 Society for Neuroscience $0270-6474 / 89 / 041362-13 \$ 02.00 / 0$
}

of these functional subtypes has not yet been achieved, but realistic routes to their production during biosynthesis have been revealed. Several cDNA clones for the alpha subunit of $\mathrm{Na}$ channels in rat brain have been described (Noda et al., 1986b), and genes coding for these products can be selectively expressed by different cells (Gordon et al., 1987; Mandel et al., 1988).

Functional attributes of a single molecularly defined "type" of $\mathrm{Na}$ channel are also modifiable by higher-order processes. Although mRNA for the alpha subunit of mammalian Na channel (brain type II) is sufficient for expression of inactivating $\mathrm{Na}$ channels in frog oocytes (Goldin et al., 1986; Noda et al., 1986b), the involvement of a much smaller, as yet unsequenced, mRNA in expression of the inactivation mechanism has been reported (Krafte et al., 1988). Na channels are also subject to extensive posttranslational modification (Schmidt and Catterall, 1986, 1987; Thornhill and Levinson, 1987), but the functional significance of these modifications, for cxample, with regard to inactivation (Cooper et al., 1987) has not been established (Agnew et al., 1988).

Regulation of neuronal $\mathrm{Na}$ channels is probably best studied with dissociated cells maintained in primary tissue culture. Electrophysiological, biochemical, and molecular techniques are all readily applicable with such in vitro systems, making them promising for studies of biosynthesis, processing, sorting, and trafficking of ion channels found in the neuronal cell membrane. A major difficulty with in vitro studies can occur, however, in extrapolating the in vitro picture of channel functional properties and spatial organization to the corresponding in vivo neuron resident in its proper nervous system. This is often a technically difficult or impossible point to resolve, because high-resolution methods applicable in vitro, e.g., patch voltage clamp, are not well suited to studies of neurons in situ.

Squid giant axons and their somata present an excellent opportunity to study $\mathrm{Na}$ channel regulation in an identified neuron with a well-established function (Young 1938; T. S. Otis and W. F. Gilly, unpublished observations). Because of the large size and anatomical simplicity of these cells, $\mathrm{Na}$ channel expression can be compared, in vivo versus in vitro, as well as in different spatial regions, e.g., soma versus axon. Functional aspects of the axonal $\mathrm{Na}$ channels have been studied extensively using classical voltage-clamp techniques and intracellularly perfused axons. The numerous cell bodies giving rise to the giant axon in the giant fiber lobe (GFL) of the stellate ganglion (Young, 1939; Martin and Miledi, 1986) have received virtually no attention, however. These neurons are accessible in situ for recordings with intracellular microelectrodes, but they are inexcitable (Miledi, 1967) and have no detectable Na current $\left(I_{\mathrm{Na}}\right)$ (Brismar and Gilly, 1987). Recent studies of acutely dissociated 
(and therefore axotomized) GFL neurons with patch-clamp techniques confirm this fact (Llano and Bookman, 1986).

The apparent lack of $\mathrm{Na}$ channels in GFL somata is significant because it indicates that a strict sorting process must occur by which functional $\mathrm{Na}$ channels, which are present at high density in the axonal membrane, are prevented from being expressed in the cell body itself. $\mathrm{Na}$ channel synthesis, which is ongoing in GFL cells in vivo, continues when the cells are dissociated and placed in primary culture, and after several days a stable level of $I_{\mathrm{Na}}$ is established with a density much lower than that normally found in the giant axon (Brismar and Gilly, 1987). Inappropriate expression of functional Na channels in cultured GFL somata depends on continued synthesis of $\mathrm{Na}$ channel mRNA and protein, the presence of intact microtubules, and the lack of an axon to serve as the appropriate target for newly synthesized channels.

We address here the question as to what degree of functional perfection can the isolated neuronal soma process and express in $\mathrm{Na}$ channels that are normally found only in its axon. We find that most $\mathrm{Na}$ channels expressed in cultured GFL cells are essentially indistinguishable from their axonal counterparts with regard to the functional properties of activation/inactivation gating and tetrodotoxin (TTX)/saxitoxin (STX) sensitivity. "Threshold" Na channels analogous to those in the giant axon (Gilly and Armstrong, 1984) are not found in cultured somata. A minor fraction of the inappropriately expressed $\mathrm{Na}$ channels in GFL cells appears to lack the inactivation mechanism of normal channels and displays an unusually high sensitivity to block by $\mathrm{Cd}$ ions.

\section{Materials and Methods}

GFL cell experiments. All results described in this paper were obtained on GFL cell bodies from Loligo opalescens isolated and cultured as previously described (Brismar and Gilly, 1987; cf. Llano and Bookman, 1986). The culture medium consisted of Leibovitz's L-15 supplemented with $6 \%$ fetal bovine serum (Gibco, Grand Island, NY) and the following salts: $9.05 \mathrm{~mm} \mathrm{CaCl}, 4.64 \mathrm{~mm} \mathrm{KCl}, 49.54 \mathrm{~mm} \mathrm{MgCl}_{2}$ and $263 \mathrm{~mm}$ $\mathrm{NaCl}$. We also added $2 \mathrm{~mm}$ L-glutamine, $50 \mathrm{U} / \mathrm{ml}$ penicillin $\mathrm{G}$, and 0.5 $\mathrm{mg} / \mathrm{ml}$ streptomycin, as $1 \%$ "glutamine pen-strep" (Irvine Scientific, Irvine, CA).

Voltage-clamp measurements employed a single-electrode, whole-cell technique of the conventional type (EPC-7 amplifier, Medical Systems, Garden City, NY). The series resistance compensation was adjusted (50-80\%) while delivering a $20 \mathrm{mV}$ hyperpolarizing voltage step with the capacity compensation turned off. Input capacity was obtained by integrating the current transient for the $20 \mathrm{mV}$ pulse, and a single time constant was fit to the decay of capacity current to calculate the effective series (access) resistance. This procedure was repeated after solution changes and at other times when deemed necessary. Passive electrical properties of each cell from which data are illustrated, along with the experimental temperature and the total time the cell was maintained in vitro, are given in the figure legends as: input capacity $(\mathrm{pF})$, compensated series resistance $(\mathrm{M} \Omega)$, temperature $\left({ }^{\circ} \mathrm{C}\right)$, and time in vitro $(\mathrm{d})$.

Currents recorded from GFL cells can be large, and it was often necessary to attenuate the output of the voltage clamp with a passive voltage divider to prevent saturation of the A-D converter in the computer interface. All signals were filtered at $10-20 \mathrm{kHz}$ with an 8-pole Bessel filter (Frequency Devices, Inc.) and sampled at $100 \mathrm{kHz}$ with an interface designed by Drs. C. M. Armstrong, R. Matteson, and R. Bookman (Department of Physiology, University of Pennsylvania) and constructed at Hopkins Marine Station. Linear ionic and capacity currents were removed from all displayed records by a standard on-line subtraction procedure $(-\mathrm{P} / 4)$ : Control pulses were $1 / 4$ the amplitude of the test pulse and were delivered from the standard holding potential of $-85 \mathrm{mV}$.

All experiments were carried out at approximately $10^{\circ} \mathrm{C}$. The external solution contained $470 \mathrm{mM} \mathrm{NaCl}, 10 \mathrm{mM} \mathrm{CaCl}, 50 \mathrm{mM} \mathrm{MgCl}$, and 10 mM Hepes ( $\mathrm{pH} 7.8)$. CsCl, $10 \mathrm{~mm}$, was sometimes added to this solution; this has no effect on results described in this paper. The internal solution for all experiments contained $100 \mathrm{~mm} \mathrm{Na}$ glutamate, $50 \mathrm{~mm} \mathrm{NaF}, 50$ $\mathrm{mM} \mathrm{NaCl}, 300 \mathrm{~mm}$ tetramethylammonium (TMA) glutamate, $10 \mathrm{~mm}$ $\mathrm{Na}_{2}$-EGTA, $25 \mathrm{~mm}$ tetraethylammonium (TEA) Cl, and $10 \mathrm{~mm}$ Hepes (pH 7.8).

The external solution in the experimental chamber was grounded via a $\mathrm{Ag} / \mathrm{AgCl}$ wire inside an agar bridge made with external solution. All (pipette) voltages reported in this paper have been corrected by -4.5 $\mathrm{mV}$ for the liquid junction potential between internal and external solutions. This value was estimated in 2 ways. (1) The voltage sensed by a recording pipette filled with internal solution was measured with a high-input-impedance electrometer upon changing the cxpcrimental bath from external to internal solution. (2) Direct measurement of membrane potential was made with a $3 \mathrm{M} \mathrm{KCl}$-filled intracellular microelectrode $(\sim 50 \mathrm{M} \Omega)$ in a GFL neuron voltage-clamped in the standard way.

Giant axon experiments. All data from giant axons reported in this paper were obtained on internally infused axons from Loligo pealei at the Marine Biological Laboratory, Woods Hole, MA, in conjunction with independent collaborative efforts with Dr. C. M. Armstrong and members of his laboratory. All methods were standard and have been described elsewhere (Bezanilla and Armstrong, 1977; Armstrong and Gilly, 1979; Gilly and Armstrong, 1982). Some of the data assembled for this paper have been adapted from these published reports, but some data were previously unpublished.

Identical experimental solutions for GFL cells and axons cannot easily be employed because of technical problems that complicate the identification of currents and that degrade performance of the voltage clamp. The major necessary differences are in the $\mathrm{Ca}$ concentrations in the external solution and in the ionic strength of the internal solution. The basic external solution for axon experiments contained $120 \mathrm{mM} \mathrm{NaCl}$, $50 \mathrm{mM} \mathrm{CaCl}_{2}, 352 \mathrm{~mm}$ Tris 7.0 (Sigma). Lower or higher levels of $\mathrm{Ca}$ were obtained by adjusting the concentration of Tris to maintain constant osmolality $(980 \mathrm{mOsm} / \mathrm{kg})$. The internal solution contained 120 mM Na glutamate, $30 \mathrm{~mm}$ TMA glutamate, $50 \mathrm{~mm}$ TMA F, $10 \mathrm{~mm}$ Tris 7.0 , and sufficient sucrose to maintain osmolality at $1000 \mathrm{mOsm} / \mathrm{kg}$. Na-free internal solutions were made as above but by replacing $\mathrm{Na}$ glutamate with TMA glutamate. Temperature for all axon experiments was $8^{\circ} \mathrm{C}$. Compensation for $3 \Omega \mathrm{cm}^{2}$ of series resistance was employed.

\section{Results}

\section{Sodium versus calcium currents in cultured GFL cells}

Sodium currents $\left(I_{\mathrm{Na}}\right)$ in GFL cells are readily identifiable by standard criteria (Brismar and Gilly, 1987). In axotomized cells that have been cultured for $6 \mathrm{~d}$ or more, $I_{\mathrm{Na}}$ is robust and displays the characteristics illustrated in Figure 1. Figure $1 A$ (upper pair of traces) shows records of $I_{\mathrm{Na}}$ accompanying a depolarizing pulse from -85 to $0 \mathrm{mV}$ in the absence and presence of 500 nM TTX. TTX-sensitive $I_{\mathrm{Na}}$ generated by direct subtraction of these traces is given in the lower panel. $I_{\mathrm{Na}}$ thus isolated activates and inactivates rapidly, and the inward tail current at the end of the pulse shows that the channels which were still open at this time close very quickly (time constant of $\sim 100 \mu \mathrm{sec}$ in Fig. 1A).

Figure $1 B$ shows that a depolarizing prepulse (to $-38 \mathrm{mV}$ for $50 \mathrm{msec}$ ) eliminates the transient inward current (upper panel) because the responsible Na channels have inactivated. Subtraction reveals a prepulse-sensitive $I_{\mathrm{Na}}$ (lower panel) that is nearly identical to that isolated by TTX-subtraction, except that inactivation is more complete. Figure $1, C, D$, shows analogous results for pulses to $+37 \mathrm{mV}$ with and without TTX (Fig. 1C) and with and without the depolarizing prepulse (Fig. $1 D$ ). $I_{\mathrm{Na}}$ is outward at this voltage but otherwise shows the same features as inward $I_{\mathrm{Na}}$ at $0 \mathrm{mV}$.

The properties demonstrated here constitute the criteria by which we define $I_{\mathrm{Na}}$ for the present: (1) fast activation (channel opening) and deactivation (closing) kinetics; (2) rapid inactivation kinetics and nearly complete inactivation produced by a small depolarizing prepulse; (3) complete block by TTX and 

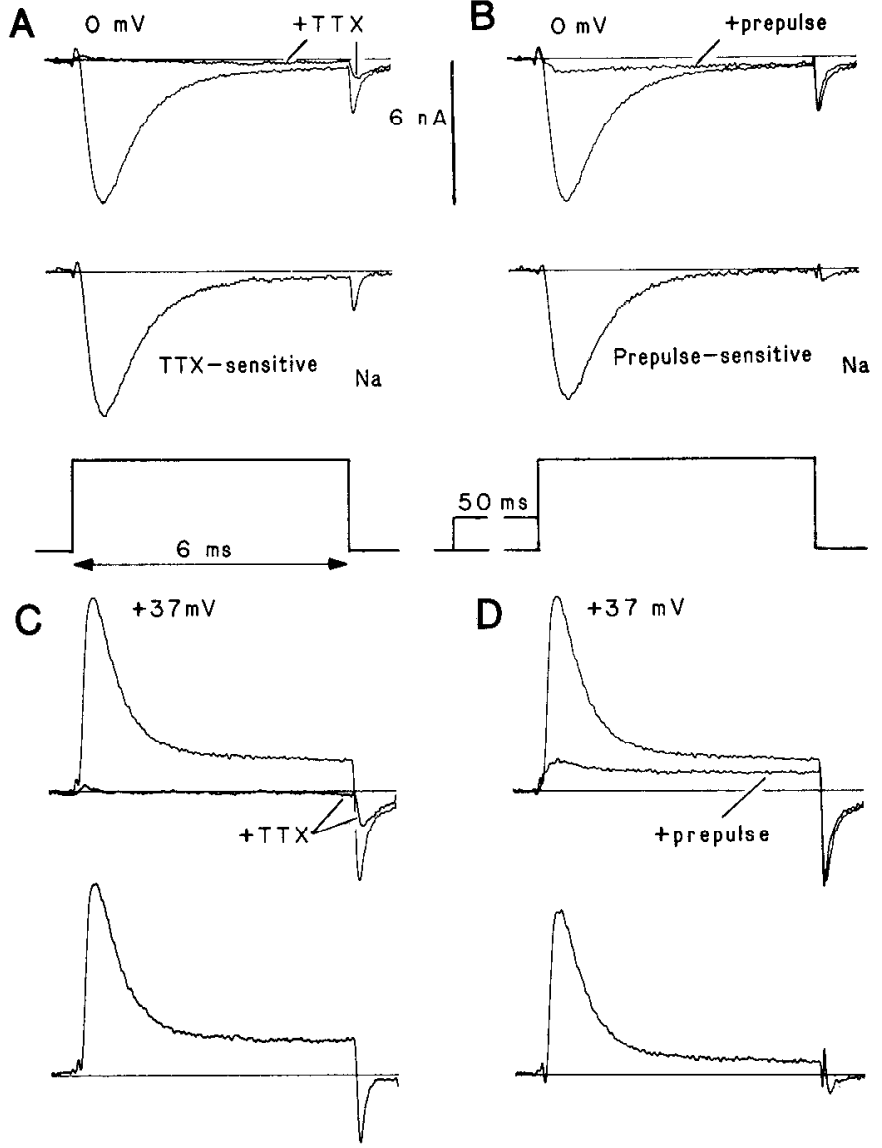

Figure 1. Identification of $I_{\mathrm{Na}}$ in GFL neurons. Pulse protocols are shown by the insets in the middle of the figure. A, Upper panel shows membrane current recorded in the absence and presence (+TTX) of $500 \mathrm{nM}$ TTX at $0 \mathrm{mV}$. TTX-sensitive $I_{\mathrm{Na}}$ is defined as the difference of the 2 records and is displayed in the lower panel. B, Upper panel shows membrane current recorded at $0 \mathrm{mV}$ with $(+$ Pre) and without a preceding depolarizing prepulse to inactivate the prepulse-sensitive fraction of Na channels. Prepulse-sensitive $I_{\mathrm{Na}}$ defined by the subtraction of these traces is shown in the lower panel. C, Outward TTX-sensitive $I_{\mathrm{Na}}$ at $+37 \mathrm{mV}$ generated as in $A$. D. Prepulse-sensitive $I_{\mathrm{Na}}$ at $+37 \mathrm{mV}$ generated as in $D$. GFL cell SE226A ( $\left.49 \mathrm{pF}, 0.9 \mathrm{M} \Omega, 12^{\circ} \mathrm{C}, 8 \mathrm{~d}\right)$.

STX (at $100 \mathrm{nM}$ or higher), and (4) defined reversal potential consistent with a high degree of $\mathrm{Na}$ selectivity.

Records in Figure $1, A, C$, show that TTX-sensitive $I_{\mathrm{Na}}$ with fast deactivation kinetics exists at the end of a pulse regardless of whether the test pulse is to 0 or $+37 \mathrm{mV}$. This "steady state" $I_{\mathrm{Na}}$ appears to be generated by an inactivation-resistant form of otherwise normal $\mathrm{Na}$ channels and will be discussed in detail below. The first part of this paper concentrates on the larger fraction of "normal," inactivating $\mathrm{Na}$ channels.

Another feature apparent in Figure 1 is a slow component of the inward tail currents that is TTX resistant and is virtually unaffected by a depolarizing prepulse. This current is probably carried mainly by $\mathrm{Ca}$ ions flowing through $\mathrm{Ca}$ channels $\left(I_{\mathrm{Ca}}\right)$ and to a lesser extent by $\mathrm{Na}$ ions passing through delayed $\mathrm{K}$ channels. Contamination of $I_{\mathrm{Na}}$ from either source is usually small compared with $I_{\mathrm{Na}}$ in GFL cells that have been cultured for 6 days or more and can be avoided. $I_{\mathrm{Ca}}$ is distinguishable from $I_{\mathrm{Na}}$ by several means (Llano and Bookman, 1986; see also below). Inward $\mathrm{Na}$ movements through $\mathrm{K}$ channels are barely detectable in GFL cells from Loligo and can be eliminated by $10 \mathrm{~mm} \mathrm{CsCl}$ in the external medium. Although this latter phenomenon is of minor importance to results in this paper on Loligo opalescens, it can be a major concern when carrying out similar experiments on other species, e.g., Lolliguncula brevis (Brismar and Gilly, 1987), and will be described in detail elsewhere.

Qualitative differences between $I_{\mathrm{Na}}$ and $I_{\mathrm{Ca}}$ in GFL cells are illustrated in Figure 2. $I_{\mathrm{Ca}}$ was recorded in the virtual absence of $I_{\mathrm{Na}}$ from a cell that had been axotomized and cultured for only $2 \mathrm{~d} ; I_{\mathrm{Na}}$ had thus not yet appeared (Brismar and Gilly, 1987). Inward current during a pulse to $-10 \mathrm{mV}$ activates and deactivates more slowly than does $I_{\mathrm{Na}}$ (compare Figs. $2 A$ and $1 A$ ). $\mathrm{CdCl}_{2}, 3 \mathrm{~mm}$, eliminates this slower inward current during the pulse and blocks most of the tail current following repolarization ( $+\mathrm{Cd}$ trace in Fig. $2 A$ ). The Cd-sensitive $I_{\mathrm{Ca}}$ generated by subtraction is shown in the lower panel. Time constant of the tail current is $\sim 500 \mu \mathrm{sec}$. Cd has only minor effects on $I_{\mathrm{Na}}$; conversely, TTX and STX have no effect on Cd-sensitive $I_{\mathrm{Ca}}$ (data not illustrated; cf. Fig. 2 of Brismar and Gilly, 1987). We have not studied the small, slow tail currents that persist in $\mathrm{Cd}$ and cannot at present identify the species of permeant ion.

Depolarizing prepulses that would completely inactivate the prepulse-sensitivie fraction of $I_{\mathrm{Na}}$ have little effect on $I_{\mathrm{Ca}}$ during a subsequent test pulse. In Figure $2 \mathrm{C}$ a $50 \mathrm{msec}$ prepulse to -38 $\mathrm{mV}$ accelerates the onset of $I_{C a}$ at $-10 \mathrm{mV}$ but has almost no effect of the final level of current or on amplitude of the tail current. This cell had no detectable $I_{\mathrm{Na}}$. If Ca channels inactivate, they must do so much more slowly than $\mathrm{Na}$ channels.

Finally, under our recording conditions $I_{\mathrm{Ca}}$ never reverses direction as shown in Figure $2 B$. Cd-sensitive current during this large depolarization is not detectable, but a large Cd-sensitive tail current of $600 \mu \mathrm{sec}$ time constant indicates the level of Ca channel activation. Apparently, the reversal potential for $I_{\mathrm{Ca}}$ is very positive, and it does not appear that $\mathrm{Na}$ ions pass outward through open $\mathrm{Ca}$ channels to a significant extent.

Thus, $I_{\mathrm{Ca}}$ is distinct from $I_{\mathrm{Na}}$ for each of the identifying criteria listed above: (1) distinctly slower activation and deactivation kinetics, (2) lack of inactivation, (3) lack of sensitivity to TTX or STX but relatively high sensitivity to $\mathrm{Cd}$, and (4) no definable reversal potential. This set of properties for $I_{\mathrm{Ca}}$ was also reported by Llano and Bookman (1986) for GFL cells in Loligo pealei studied under almost identical conditions. Cd block of $I_{\mathrm{Ca}}$ has been studied in detail by Chow and Armstrong (1988).

\section{Adequacy of voltage control in GFL cells}

Because of the steep voltage dependence and rapid kinetics associated with changes in $\mathrm{Na}$ conductance $\left(G_{\mathrm{Na}}\right)$, care must be exercised in using any voltage-clamp technique, especially one relying on a single electrode. Figure 3 demonstrates the adequacy with which $V_{m}$ was controlled in our experiments on GFL cells. In Figure $3 A$ (upper panel), the $I_{\mathrm{Na}}$ trace labeled (1) was recorded from a large GFL cell in the usual way with the whole-cell method. A second electrode, operating in current-clamp mode, was then sealed onto the cell, and after breaking the membrane patch with suction, the $V_{m}$ change shown in the lower panel was recorded along with $I_{\mathrm{Na}}(2)$. Figure $3 B$ shows $I_{\mathrm{Na}}$ and $V_{m}$ after increasing the series resistance compensation and thereby lowering the effective access resistance. Voltage control during the pulse is good, and activation kinetics can clearly be resolved.

The ability of the whole-cell method to control $V_{m}$ rapidly enough to measure faster kinetic properties of $I_{\mathrm{Na}}$ is tested more critically in Figure $3 C$. $I_{\mathrm{Na}}$ during a $1 \mathrm{msec}$ pulse to $-10 \mathrm{mV}$ and the tail current following repolarization to $-66 \mathrm{mV}$ are 


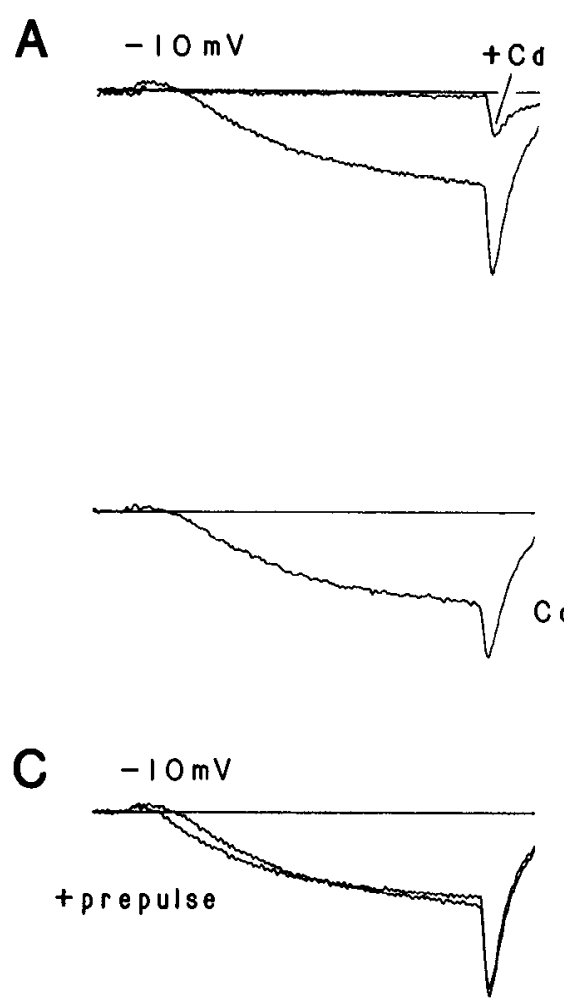

B
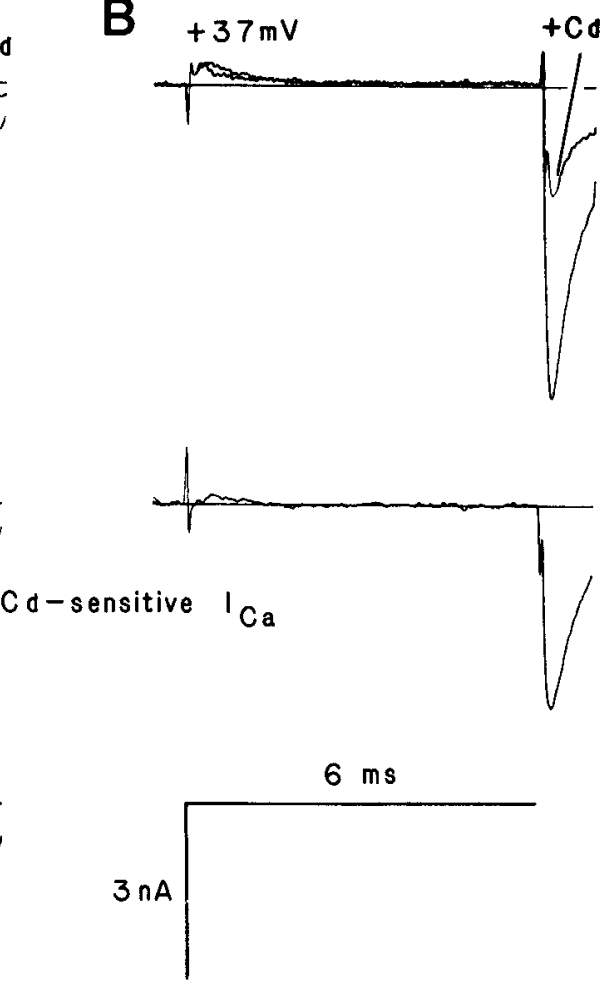

Figure 2. Identification of $I_{\mathrm{Ca}}$ in GFL cells. $I_{\mathrm{Na}}$ is absent because the cells have not been maintained in vitro long enough after axotomy. $A$, Membrane current recorded at $-10 \mathrm{mV}$ in the absence and presence $(+\mathrm{Cd})$ of $3 \mathrm{mM} \mathrm{CdCl}$. Cdsensitive $I_{C a}$ is generated by subtraction of the traces and is displayed in the lower panel. $B$, Analogous results at +37 $\mathrm{mV}$. Cd-sensitive $I_{\mathrm{Ca}}$ is essentially zero during the pulse, but a large inward $I_{C a}$ tail flows after the pulse. $C$, Current recorded at $-10 \mathrm{mV}$ with (+Pre) and without a depolarizing prepulse (to -38 $\mathrm{mV}$ for $50 \mathrm{msec}$ ). The prepulse produces no inactivation of $I_{\mathrm{Ca}}$. GFL cell $0 \mathrm{C} 036 \mathrm{C}$ (94 pF, $\left.1.5 \mathrm{M} \Omega, 10.5^{\circ} \mathrm{C}, 2 \mathrm{~d}\right)$. illustrated along with the independently measured $V_{m}$. The time courses of $V_{m}$ and $I_{\mathrm{Na}}$ at the end of the $1 \mathrm{msec}$ pulse are more easily compared in Figure $1 D$, where the $V_{m}$ trace has been inverted and scaled so that the repolarizing transition matches the measured peak $I_{\mathrm{Na}}$ tail in amplitude. $V_{m}$ changes with a time constant of $54 \mu \mathrm{sec}$ (solid line fit) and has nearly reached its final level when a large $I_{\mathrm{Na}}$ tail is still flowing. This tail current decays with a time constant of $98 \mu \mathrm{sec}$. Although the measured rate of channel closing must be influenced by the speed of $V_{m}$ changes in this experiment, the method is adequate for obtaining an upper limit for closing time constant and for differentiating $I_{\mathrm{Na}}$ and $I_{\mathrm{Ca}}$ tail currents.

Another conventional, though less direct, indicator of good voltage control is the gradually changing kinetics and amplitude of $I_{\mathrm{Na}}$ over a large series of activating voltages. The shape of the $I_{\mathrm{Na}}$-voltage relation in the region of negative slope is especially sensitive to poor control. In Figure $4 A$, TTX-sensitive $I_{\mathrm{Na}}$ was recorded at each labeled voltage with and without a depolarizing prepulse to inactivate the "normal" $\mathrm{Na}$ channels. The relation between peak $I_{\mathrm{Na}}$ (measured without prepulses) and pipetle vollage $(V)$ is plotted in Figure $4 B$ (circles). There is no sign of any discontinuity in the smooth curve defined, and the reversal potential of $+17 \mathrm{mV}$ agrees well with an expected value of +18.5 $\mathrm{mV}$ for a perfect $\mathrm{Na}$ electrode.

Finally, it is important to demonstrate that the above features of $I_{\mathrm{Na}}$ and $I_{\mathrm{Na}}-V$ relation are independent of parameters such as cell size, specific density of $I_{\mathrm{Na}}$, or the amount of neurite outgrowth. GFL cells under our culture conditions do not extend neurites, but $I_{\mathrm{Na}}$ density and possibly cell size increase over time in culture. The $I_{\mathrm{Na}}-V$ relation obtained in a small GFL cell is also plotted in Figure $4 B$ (triangles). This curve is shaped almost identically to that for the larger cell with twice the peak inward current density ( $1 \mathrm{nA} / 33 \mathrm{pF}$ vs. $6 \mathrm{nA} / 98 \mathrm{pF}$, respectively). Thus, we do not see any difference in the properties of $I_{\mathrm{Na}}$ in cells of different size. The density of $I_{\mathrm{Na}}$ is also independent of cell size in "fully matured" GFL cells cultured for 9-13 d (cf. Brismar and Gilly, 1987), and the total $G_{\mathrm{Na}}$ (determined as described below) increases approximately linearly with cell surface area (Fig. 5).

The overall conclusion is that our method of voltage clamp can be used with GFL cells to give reliable information about the relevant properties of $G_{\mathrm{Na}}$. In the following sections these properties will be described and compared with data from the giant axon.

\section{Voltage dependence of $\mathrm{Na}$ channel activation}

$G_{\mathrm{Na}}$-voltage relations were derived from peak $I_{\mathrm{Na}}-V$ curves as $G_{\mathrm{Na}}=I_{\mathrm{Na}} /\left(V-V_{\mathrm{Na}}\right)$, where $V_{\mathrm{Na}}$ is the measured reversal potential. This formulation applies well to giant axons at depolarized voltages, and we assume its applicability to GFL cells as well. Figure $6 A$ shows the $G_{\mathrm{Na}}-V$ relation for data (circles) from Figure $4 B$. "Threshold" for $\mathrm{Na}$ channel activation lies around -40 $\mathrm{mV}, 50 \%$ of maximal $G_{\mathrm{Na}}$ is activated at approximately -10 $\mathrm{mV}$, and saturation is reached around $+20 \mathrm{mV}$.

Results in Figure $6 A$ are typical, and $G_{\mathrm{Na}}-V$ relations for 3 GFL cells are given in Figure $6 B$ (filled symbols). The $50 \%$ level varies between -20 and $-10 \mathrm{mV}$. Data from 2 giant axons recorded under similar ionic conditions are also illustrated (open symbols). Shapes of all the $G_{\mathrm{Na}}-V$ curves are very similar, and the voltage dependence of $\mathrm{Na}$ channel activation in GFL cells in vitro and their daughter axons in vivo thus appears to be the same.

Figure 7 indicates the voltage dependence of $G_{\mathrm{Na}}$ for small depolarizations near threshold for detection of $I_{\mathrm{Na}}$. Sixteen sweeps were averaged at each indicated voltage to obtain the TTXsensitive $I_{\mathrm{Na}}$ records illustrated in Figure $7, A, B$ (2 different 

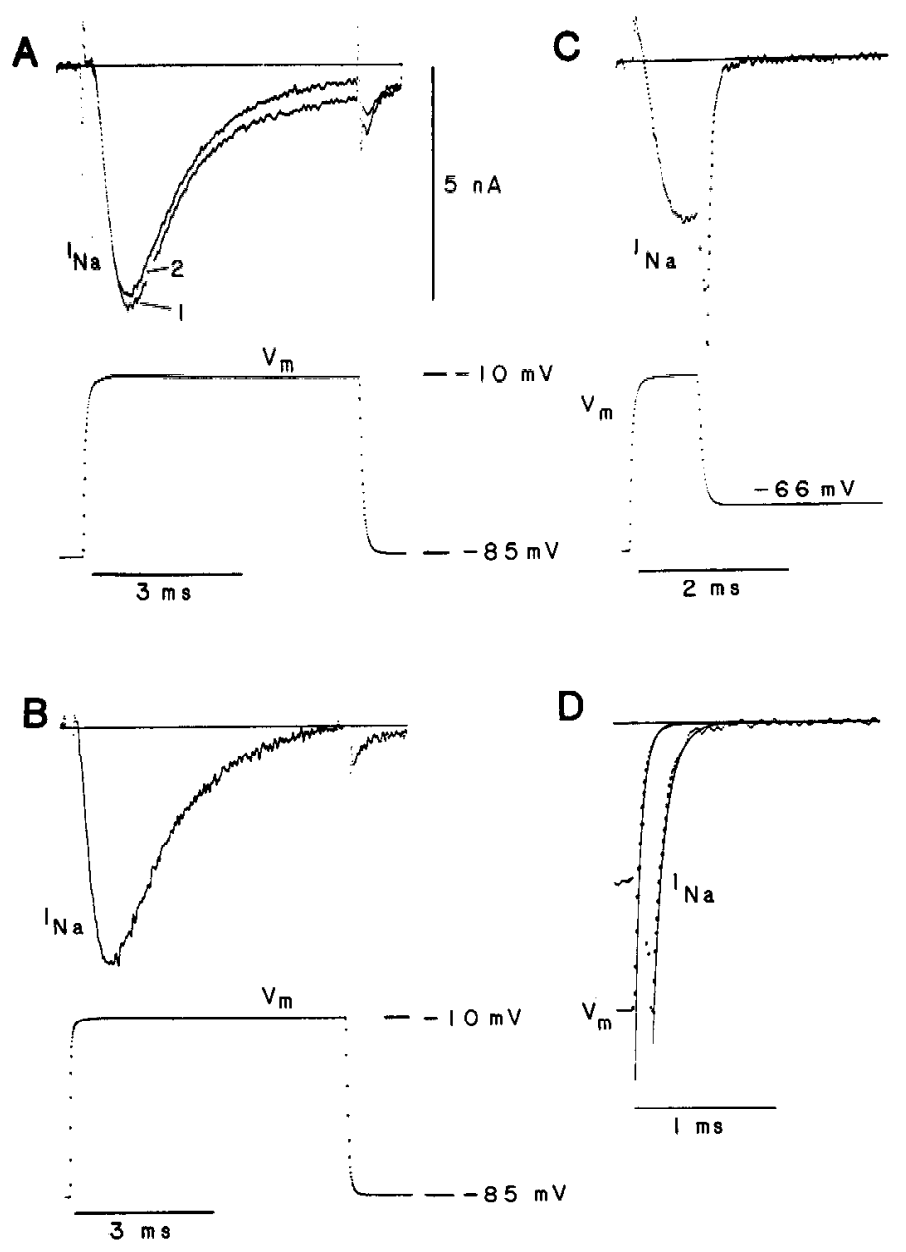

Figure 3. Independent measurement of membrane voltage $\left(V_{m}\right)$ in a GFL cell in the presence of large inward $I_{\mathrm{Na}} . A, I_{\mathrm{Na}}$ at $-10 \mathrm{mV}$ was recorded just before (1) and after (2) breaking into the cell with a second electrode operating in the current-clamp mode to measure $V_{m} . B, I_{\mathrm{Na}}$ and $V_{m}$ records obtained after increasing the series resistance compensation from 50 to $80 \% . C, I_{\mathrm{Na}}$ and $V_{m}$ records for a brief pulse in order to measure the $I_{\mathrm{Na}}$ tail current at $-66 \mathrm{mV}(70 \%$ series resistance compensation). $D$. Comparison of the time course of $V_{m}$ change and the $I_{\mathrm{Na}}$ tail. Smooth curves are exponentials fitted to the data points. See text for details. GFL cell SE246W (149 pF, $\left.0.26 \mathrm{M} \Omega, 11^{\circ} \mathrm{C}, 4 \mathrm{~d}\right)$.

cells). Corresponding values of peak $G_{\mathrm{Na}}$ for each record were obtained as described above, normalized to maximal $G_{\mathrm{Na}}$ (measured at $+30 \mathrm{mV}$ ), and plotted against $V$ in Figure $7 C . G_{\mathrm{Na}}$ in GFL cells increases $e$-fold per $4.5 \mathrm{mV}$, and this high degree of voltage sensitivity is similar to that of $G_{\mathrm{Na}}$ in giant axons, where values of $4.2 \mathrm{mV}$ (Hodgkin and Huxley, 1952) to $5.3 \mathrm{mV}(\mathrm{Ox}-$ ford, 1981) have been reported.

\section{Activation kinetics of $\mathrm{Na}$ channels}

Voltage dependencies of $\mathrm{Na}$ channel opening and closing kinetics determine the time course of $I_{\mathrm{Na}}$ activation at a given test voltage and of deactivation following repolarization. Because there is no straightforward, model-independent relationship between channel kinetics and the time course of the $I_{\mathrm{Na}}$ waveform (French and Horn, 1983; Armstrong and Matteson, 1984), the following analysis was carricd out for comparative purposes.

Figure $8 A$ shows the time course of TTX-sensitive $I_{\mathrm{Na}}$ development at several indicated voltages. All records have been scaled to the same peak amplitude and plotted as outward cur- rent to facilitate kinetic comparison. Half-time to peak $I_{\mathrm{Na}}$ (Opening Half Time) is plotted versus $V$ in Figure $8 B$ for $3 \mathrm{GFL}$ cells (filled symbols) and 2 giant axons (open symbols). The 2 sets of values overlap over much of the voltage range, but giant axon $I_{\mathrm{Na}}$ appears to activate somewhat faster at very positive voltages.

Channel-closing kinetics largely govern the time course of tail currents after an activating pulse, and examples of $\bar{I}_{\mathrm{Na}}$ tails rècorded at different voltages are shown in Figure $8 \mathrm{C}$. Single exponentials were fit to TTX-sensitive $I_{\mathrm{Na}}$ tails and values of the time constants thus derived are plotted versus $V$ for $3 \mathrm{GFL}$ cells in Figure $8 D$ (filled symbols) and compared with data from a single giant axon studied in both $20 \mathrm{~mm} \mathrm{Ga} \mathrm{(open} \mathrm{triangles)} \mathrm{and}$ $100 \mathrm{~mm} \mathrm{Ca}$ (open circles). GFL cell and axon data are again similar, although $I_{\mathrm{Na}}$ in GFL cells appears to turn off slightly faster than in axons at voltages positive to $-70 \mathrm{mV}$,

\section{Inactivation of $\mathrm{Na}$ channels}

"Steady state" inactivation was studied by delivering $50 \mathrm{msec}$ prepulses of variable amplitude, to produce inactivation, followed immediately by a fixed test pulse to $+47 \mathrm{mV}$ (see inset to Fig. $9 A$ ). The amount of inactivating TTX-sensitive $I_{\mathrm{Na}}$ was determined for each prepulse voltage by subtraction of each prepulsed trace $\left(I_{+ \text {pre }}\right)$ from that obtained with the prepulse equal to the holding potential of $-85 \mathrm{mV}\left(I_{- \text {pre }}\right)$. The relative value of the resultant prepulsc-scnsitive current (i.e., $\Delta I_{\text {pre }}=I_{- \text {pre }}-$ $I_{+ \text {pre }}$ ) was obtained as $1-\Delta I_{\text {pre }} / I_{- \text {pre }}$.

Data are plotted in Figure $9 A$ for 3 GFL cells (filled symbols), and a midpoint of approximately $-45 \mathrm{mV}$ is evident. Neither the shape of the inactivation- $V$ relation nor its midpoint are distinguishable from corresponding data in giant axons (open symbols in Fig. 9A).

The kinetics of inactivation were assessed either by fitting a single exponential to the falling phase of TTX-sensitive $I_{\mathrm{Na}}$ (for larger pulses) or at more negative voltages (where little current activates) by applying a depolarizing prepulse of fixed amplitude and varying duration followed by a constant test pulse to +47 $\mathrm{mV}$. A straight-line fit to a semilog plot of the decrease in $I_{\mathrm{Na}}$ versus prepulse duration defined the time constant for inactivation (not illustrated). When both methods were applied at the same voltage, they yielded equivalent values (see also Armstrong and Bezanilla, 1977).

Figure $9 B$ shows results from 3 GFL cells (filled symbols) and a giant axon (open circles). At very positive voltages, GFL cell and axon curves converge, but for smaller depolarizations (e.g., $-20 \mathrm{mV}$ ), inactivation in GFL cells is more rapid. This is not due to the small temperature difference between axon and GFL cell data (8 vs $10^{\circ} \mathrm{C}$, respectively) or to differences in Ca levels (50 mm Ca vs $10 \mathrm{~mm} \mathrm{Ca}+50 \mathrm{~mm} \mathrm{Mg}$, respectively). This was demonstrated by studying a GFL cell at both 8 and $10^{\circ} \mathrm{C}$ (filled circles vs squares) and another cell in both $10 \mathrm{~mm} \mathrm{Ca}+50 \mathrm{Mg}$ and $50 \mathrm{~mm} \mathrm{Ca}+50 \mathrm{Mg}$ (stars vs cross).

\section{GFL cells do not express threshold channels in vitro}

A small fraction $(<5 \%)$ of $\mathrm{Na}$ channels in perfused giant axons represents a distinct $\mathrm{Na}$ channel subtype labeled "threshold channels" (Gilly and Armstrong, 1984). Like the normal axonal Na channels, threshold channels are blocked by low concentrations of TTX. In distinction from the normal channels, however, threshold channels open at abnormally negative voltages and close very slowly. This combination of features permits study 
A

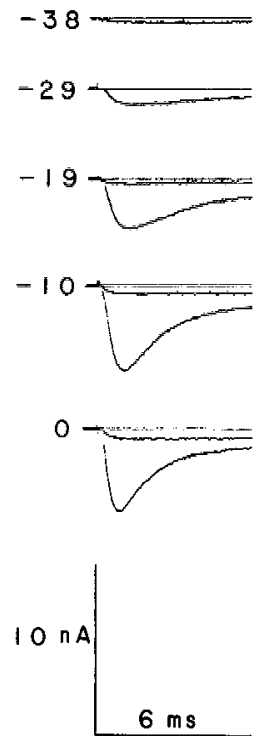

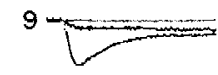
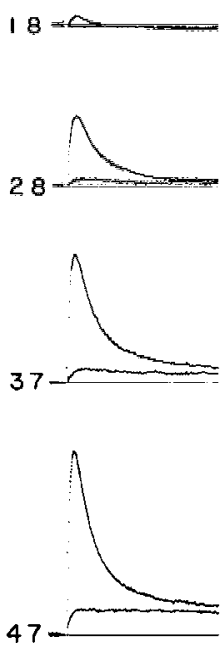

B

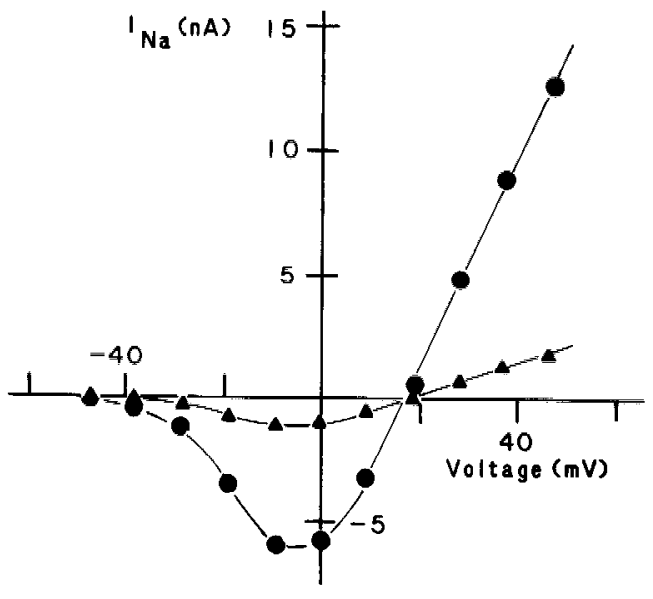

Figure 4. Behavior of $I_{\mathrm{Nin}}$ over a seriès of activating voltages and the $I_{\mathrm{Na}}$-voltage relation. $A, \overline{\mathrm{TTX}}$-sensitive $\bar{I}_{\mathrm{Sdi}}$ recorded at the labeled voltages with and without a prepuilse $(50 \mathrm{msec}$ to -34 $\mathrm{mV}) . B, I_{\mathrm{Na}}-V$ relation measured from peak $I_{\mathrm{N} d}$ in $A$ (records without prepulses) is indicated by the circles (O). Triangles $(\mathbf{\Lambda})$ are data from a smaller cell with a lower density of $I_{\mathrm{Na}}$.'Prepulsesensitive $I_{\mathrm{Na}}$ (see Fig. 1) was plotted for this cell. GFL cell for $A$ and (O) in $B$ : OC086J $\left(105 \mathrm{pF}, 0.65 \mathrm{M} \Omega, 10.5^{\circ} \mathrm{C}, 6\right.$ d); (A) in $B:$ SE186I (33 pF, $1.3 \mathrm{M} \Omega$, $14^{\circ} \mathrm{C}, 4 \mathrm{~d}$ ). of threshold channels through analysis of tail currents following small depolarizations.

Figure 10 shows results of an experiment designed to test for the presence of threshold channels in a cultured GFL cell. Inward tail currents in the absence and presence of $100 \mathrm{~nm}$ TTX were recorded at $-85 \mathrm{mV}$ following small activating pulses to $-43 \mathrm{mV}$ (Fig. 10A) and $-38 \mathrm{mV}$ (Fig. 10B). These voltages would be appropriate to selectively activate most threshold channels in an axon. Tail currents with and without TTX are given in the upper panels of Figure $10, A, B$, and the TTXsensitive current obtained by subtraction is displayed in the lower panels. No TTX-sensitive inward $I_{\mathrm{Na}}$ tail with slow kinetics is detectable, and the TTX-insensitive tail currents are probably $I_{\mathrm{Ca}}$.

Figure $10 C$ shows the $I_{\mathrm{Na}}$ tail following a brief pulse to -10 $\mathrm{mV}$, which is entirely due to activation of normal, rapidly closing $\mathrm{Na}$ channels. If threshold channels were activated during the pulse, their presence should be manifested by a small, slow component of the tail current. No such tail is detectable, and Figure $10 D$ shows the final portion of the $I_{\mathrm{Na}}$ tail of Figure $10 \mathrm{C}$ plotted at higher gain. The broken line in Figure $10 \mathrm{D}$ indicates the level of current equal to $1 \%$ of the peak inward tail amplitude in Figure $10 \mathrm{C}$. If threshold channels in GFL cells were present at a similar relative density (compared with normal channels) as in the giant axon, they should be easily detectable in Figure 10. No sign of threshold channels was evident in any cell thus examined, and we conclude that functional threshold channels are not expressed in GFL somata cultured sufficiently long to express a large amount of normal $G_{\mathrm{Na}}$.

\section{Identification of noninactivating $\mathrm{Na}$ channels}

A regular fcaturc of cultured GFL cells is the presence of a sizeable, although variable, amount of TTX-sensitive and inactivation-resistant current that reverses direction near the $V_{\mathrm{Na}}$ estimated for peak $I_{\mathrm{Na}}$. Figure 1 shows examples of such a current that also displays the fast tail current kinetics that are diagnostic for Na channels in GFL cells $(\sim 100 \mu$ sec time constant at -85 $\mathrm{mV}$ ). Other examples of noninactivating $I_{\mathrm{Na}}$ are presented for a large range of activating voltages in Figure $4 \mathrm{~A}$. From examination of these records it is evident that turn-on kinetics of this unusual fraction of $I_{\mathrm{Na}}$ are also similar to those for the normally inactivating fraction.

\section{Properties of noninactivating versus inactivating $\mathrm{Na}$ channels}

Figure $11 \mathrm{~A}$ shows the TTX-sensitive $I_{\mathrm{Na}}-V$ curves for both peak current (filled circles) recorded without a prepulse and the steadystate current (open circles) following a prepulse from the rccords in Figure $4 A$. The $I_{\mathrm{Na}}-V$ curve defined by the prepulse-resistant current is similar in shape to that for peak current, and the corresponding $G_{\mathrm{Na}}-V$ curves for both forms of $I_{\mathrm{Na}}$ are given in Figure $11 B$. Voltage dependence of the 2 types of $G_{\mathrm{Na}}$ appears to be identical.

Thus, both normally inactivating and noninactivating $G_{\mathrm{Na}}$ exist in single cultured GFL cells. The fraction of noninactivating channels is variable from cell to cell (see also below), but a detectable level always exists. We find that the 2 types of

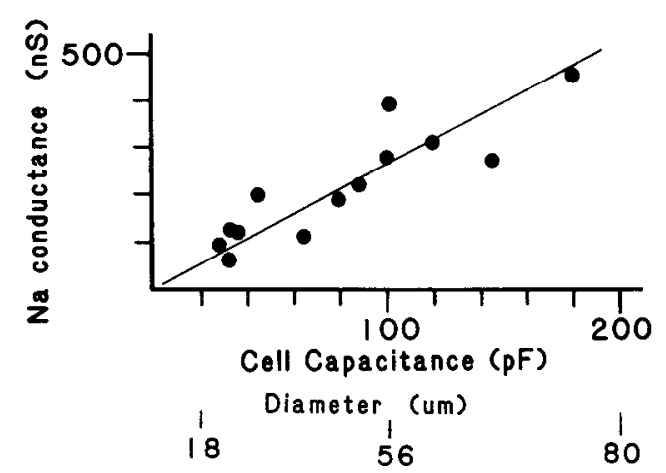

Figure 5. Dependence of absolute amount of $\mathrm{Na}$ conductance on cell surface area of GFL neurons cultured for $9-13 \mathrm{~d}$. Data plotted are from the control cells in Figure 3 of Brismar and Gilly (1987). Conductance was obtained as described in the text; cell surface area was determined electrically as capacitance. An equivalent diameter was calculated by assuming a spherical cell with a specific capacity of $1 \mu \mathrm{F} / \mathrm{cm}^{2}$. 

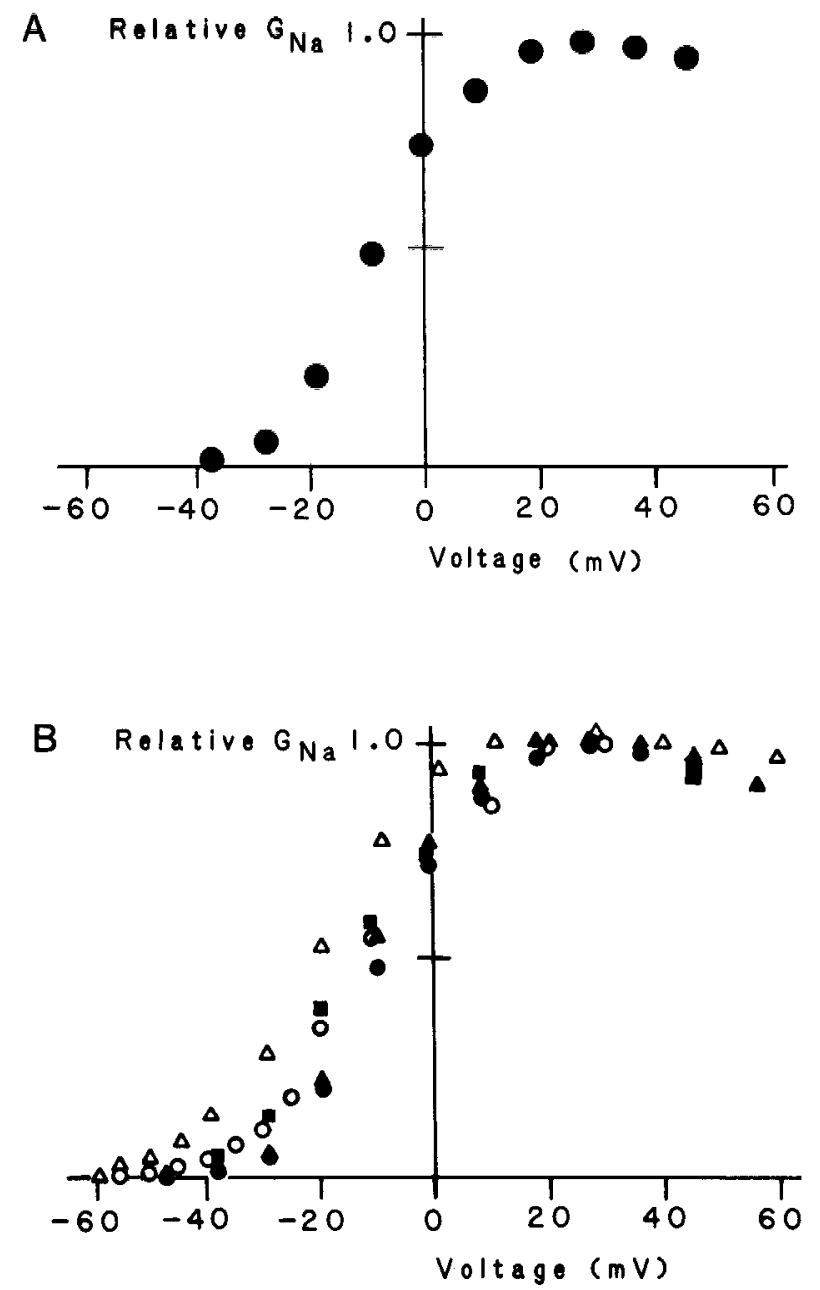

Figure 6. $G_{\mathrm{Na}}$-voltage relation for GFL cells versus giant axons. $A, G_{\mathrm{Na}}$ was determined from the peak TTX-sensitive $I_{\mathrm{Na}}$ (measured with no prepulse) from the experiment described in conjunction with Figure 4, $A, B$. Maximal $G_{\mathrm{Na}}$ was $421 \mathrm{nS}$. $B$, Normalized $G_{\mathrm{Na}}-V$ relations from 3 GFL cells ( filled symbols) are plotted with data from 2 giant axons (open symbols). GFL cells: (๑) OC086J (cf. Fig. 4); (৯) MAY12B (42 pF, 1.0 $\mathrm{M} \Omega, 10^{\circ} \mathrm{C}, 10 \mathrm{~d}$ ); (元) NO196A (112 pF, $\left.0.82 \mathrm{M} \Omega, 10^{\circ} \mathrm{C}, 5 \mathrm{~d}\right)$. Giant axons: (O) JN305C.TLS, perfused with $62.5 \mathrm{~mm} \mathrm{Na}+50 \mathrm{~mm} \mathrm{Ca}$ externally and $120 \mathrm{~mm} \mathrm{Na}+80 \mathrm{~mm}$ TMA internally; $(\triangle)$ JN153H.TLS, perfused with $120 \mathrm{~mm} \mathrm{Na}+20 \mathrm{~mm} \mathrm{Ca}$ externally and $120 \mathrm{~mm} \mathrm{Na}+$ $80 \mathrm{mM}$ TMA internally.

conductance cannot be readily distinguished on the basis of either voltage dependence or activation/deactivation kinetics.

Another common feature of the inactivating and noninactivating types of $G_{\mathrm{Na}}$ is their sensitivity to TTX and STX. Figure $12 \mathrm{~A}$ shows $I_{\mathrm{Na}}$ recorded in the absence and presence of $10 \mathrm{nM}$ TTX. Peak current and current at the end of the large activating pulse to $+47 \mathrm{mV}$ arc similarly blocked $(\sim 50 \%)$, as is the prepulse-resistant $I_{\mathrm{Na}}$ (Fig. 12B). Thus, each type of $G_{\mathrm{Na}}$ must have a $K_{d}$ for TTX of approximately $10 \mathrm{nM}$. Figure $12 C$ shows results from another cell using STX, rather than TTX, and $I_{\mathrm{Na}}$ records at 0,10 , and $100 \mathrm{nM}$ STX concentrations are illustrated. In Figure $12 D$ the difference currents are plotted for 0 and $10 \mathrm{nM}$ STX $(0-10)$ and for 10 and 100 nM STX (10-100). The 2 traces are not distinguishably different in shape, and this is better demonstrated in Figure 12E, where the $10-100$ record is replotted along with a scaled version of the $0-10$ trace. This shows that the $I_{\mathrm{Na}}$ sensitive to $10 \mathrm{nM} \operatorname{STX}(0-10)$ and that resistant to
10 nM but blocked by $100 \mathrm{nM}$ STX $(10-100)$ have the same time course. This could be possible only if both inactivating and noninactivating $G_{\mathrm{Ni}}$ were equally sensitive to STX with $K_{d}$ values of less than $10 \mathrm{~nm}$.

\section{Variability in the amount on noninactivating $\mathrm{G}_{N a}$}

We believe that the 2 varieties of $G_{\mathrm{Na}}$ described above represent 2 distinct forms of the Na channel that are expressed in GFL cells. One of these is functionally distinguishable from normal axonal Na channels in only minor ways, if at all. The other type of $\mathrm{Na}$ channel lacks inactivation but is otherwise very similar to the Na channels normally found in the giant axon.

The fraction of inactivation-resistant $G_{\mathrm{Na}}$ varies considerably from one cell to another. The mean ratio of noninactivating to peak $I_{\mathrm{Na}}$ for large depolarizations was $0.173 \pm 0.103$ (SD) in 14 GFL cells suitably studied. The relationship of this fraction versus the density of peak inward $I_{\mathrm{Na}}$ and $I_{\mathrm{Ca}}$ in these cells is plotted in Figure 13, $A$ and $B$, respectively. No correlation with $I_{\mathrm{Ca}}$ density is apparent. A reasonable correlation exists in Figure $13 A$ with peak $I_{\mathrm{Na}}$ density below values of a $0.05 \mathrm{nA} / \mathrm{pF}$ but not for cells with higher peak $I_{\mathrm{Na}}$ density. Total time in culture for these cells showed no correlation with the proportion of noninactivating $G_{\mathrm{Na}}$. The large degree of variability suggests that there is no definite functional relationship (i.e., a kinetic equilibrium) between the 2 forms of $G_{\mathrm{Na}}$, which are otherwise remarkably consistent in their properties.

\section{Block of noninactivating $\mathrm{G}_{N a}$ by cadmium ions}

A final difference between the noninactivating and inactivating types of $G_{\mathrm{Na}}$ is that noninactivating, TTX-sensitive Na can be preferentially blocked by external Cd. Furthermore, inward current through the noninactivating channels is more readily blocked than outward $I_{\mathrm{Na}}$.

Figure $14 A$ shows inward $I_{\mathrm{Na}}$ recorded at $-9 \mathrm{mV}$ in the absence and presence $(+\mathrm{Cd})$ of $2 \mathrm{mM} \mathrm{CdCl}$. Cd slows $I_{\mathrm{Na}}$ activation slightly (sce also Gilly and Armstrong, 1982) and produces a large block of current at the end of the pulse and almost complete abolition of the fast inward tail current. These latter effects cannot simply reflect blockage of inward $I_{\mathrm{Ca}}$ by $\mathrm{Cd}$ for 3 reasons.

First, the Cd-sensitive tail current following the pulse (-prepulse, Cd-sensitive tail in Fig. 14B) is demonstrably faster than $I_{\mathrm{Ca}}$ tails (see Fig. 2) and is fit by a time constant of $108 \mu \mathrm{sec}$, a value similar to that describing the essentially pure $I_{\mathrm{Na}}$ tail $(85$ $\mu \mathrm{sec}$ ) recorded after a $0.5 \mathrm{msec}$ activating pulse (left panel of Fig. 14B). This fast $I_{\mathrm{Na}}$ tail is not blocked by Cd (not illustrated). Effects of $\mathrm{Cd}$ on prepulse-resistant inward current during the pulse to $-9 \mathrm{mV}$ (Fig. 14C) and on the fast (102 $\mu \mathrm{sec}$ time constant) tail current afterwards (+prepulse, Cd-sensitive tail in Fig. 14B) are similar to those described in conjunction with Figure $14 \mathrm{~A}$.

A sccond reason for identifying the noninactivating, Cd-sensitive current in Figure 14 as $I_{\mathrm{Na}}$ is that $\mathrm{Cd}$ also blocks outward current, presumably through the same channels, during a large depolarization beyond $V_{\mathrm{Na}}$ (but not $V_{\mathrm{Ca}}$ ). Outward current at the end of the pulse in Figure $14 D$ is reduced by $\mathrm{Cd}$, and the large fast tail current following the pulse is eliminated. Figure $14 E$ shows analogous results for prepulse-resistant current. Because $I_{\mathrm{Ca}}$ is never outward under our recording conditions (see Fig. 2 ), the identification of Cd-sensitive current in Figure 14 as noninactivating $I_{\mathrm{Na}}$ is reinforced.

The third reason for this conclusion is indicated by STX- 
A

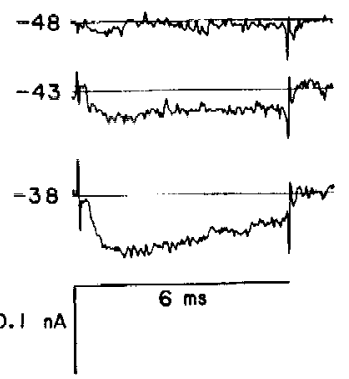

B

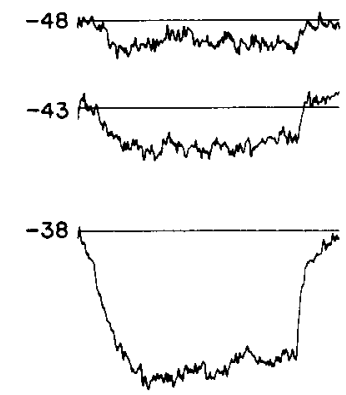

C

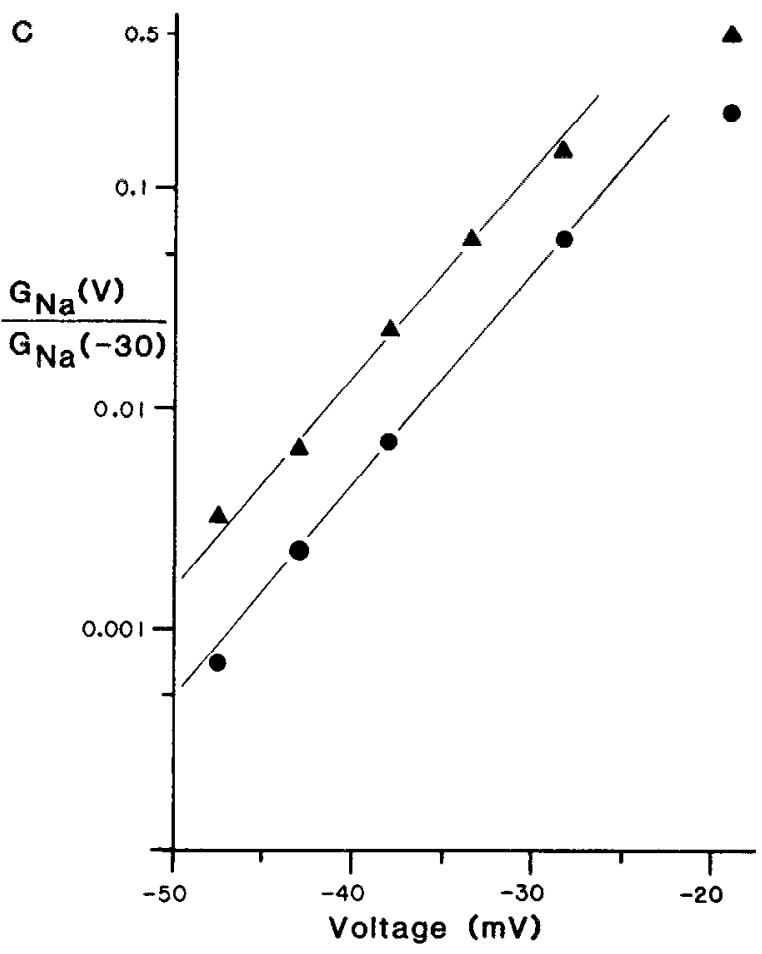

Figure 7. Limiting voltage dependence of $G_{\mathrm{Na}}$ at very negative voltages. $A$ and $B$, TTX-sensitive $I_{\mathrm{Na}}$ records were obtained at the indicated voltages in the GFL cells $(A)$ OC086J (cf. Fig. 4) and (B) $0 \mathrm{C} 086 \mathrm{~K}\left(83 \mathrm{pF}, 1.4 \mathrm{M} \Omega, 10.5^{\circ} \mathrm{C}, 6\right.$ d). $C$, Values of peak TTX-sensitive $I_{\mathrm{Na}}$ from these experiments are plotted versus voltage. The straight lines (fit by eye) have a slope indicating an $e$-fold change in $G_{\mathrm{Na}}$ per $4.5 \mathrm{mV}$. block of these Cd-sensitive currents. Figure $14 F$ shows records obtaincd for pulses to $+47 \mathrm{mV}$, with and without a prepulse, in the presence of $100 \mathrm{~nm} \mathrm{STX} \mathrm{(plus} 2 \mathrm{~mm} \mathrm{Cd}$ ). Block of the outward prepulse-resistant current that is associated with $\mathrm{Cd}$ sensitivity and fast closing kinetics (i.e., the $+\mathrm{Cd}$ trace in Fig.
$14 E$ ) by STX unambiguously associates this current with the noninactivating population of $\mathrm{Na}$ channels.

Thus, Cd can eliminate inward current through the inactivation-resistant $\mathrm{Na}$ channels, especially at highly negative voltages where tail currents are measured. At more depolarized
A
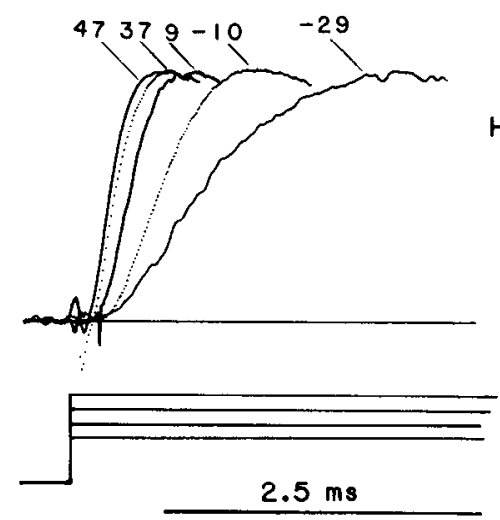

B

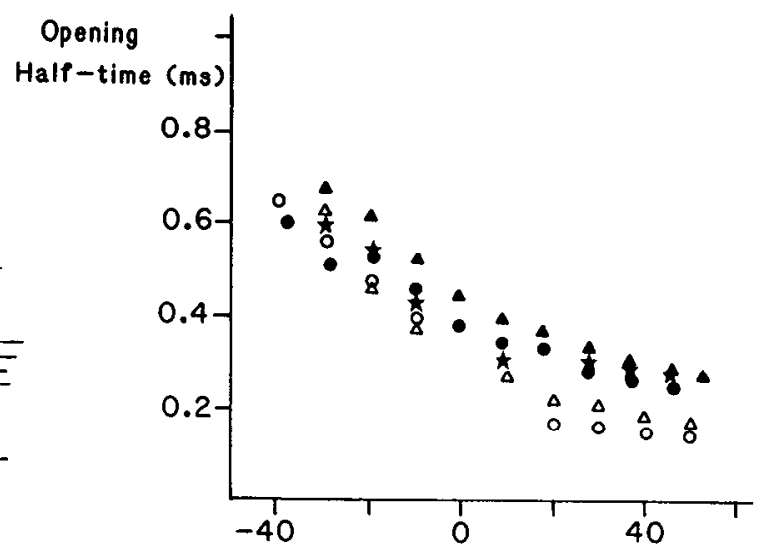

C
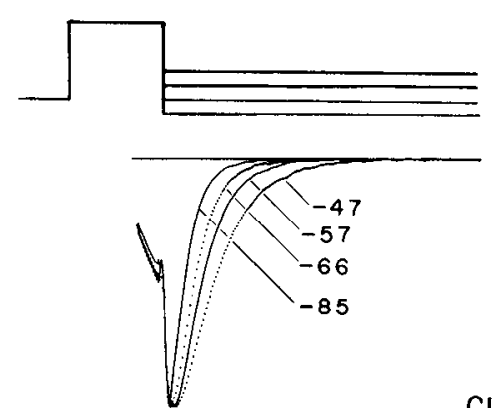

D

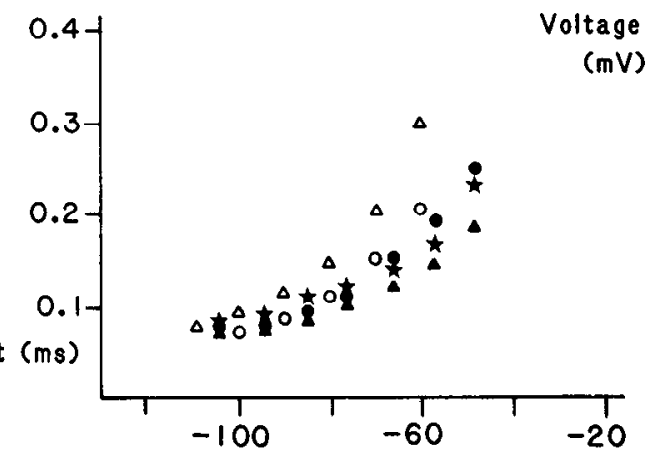

Figure 8. Activation and deactivation kinetics of $\mathrm{Na}$ channels in GFL cells versus giant axons. Inset, Pulse protocols. $A$, Comparison of $I_{\mathrm{Na}}$ turn-on kinetics at the labeled voltages. All records have been scaled to the same peak and plotted as outward current. GFL cell OC086K (cf. Fig. 7). $B$, Time to $50 \%$ pcak $I_{\mathrm{Na}}$ following a step voltage change from $-85 \mathrm{mV}$ plotted versus activating $V$ for $3 \mathrm{GFL}$ cells; (-) OC086J (cf. Fig. 4), (А) MAY12B (cf. Fig. 6), (*) NO196A (cf. Fig. 6), and 2 giant axons: $(\triangle)$ JN183G.CAO and (O) JN153H.TLS. Both axons were perfused externally with $120 \mathrm{~mm} \mathrm{Na}+20$ $\mathrm{mm} \mathrm{Ca}$ and internally with $120 \mathrm{~mm} \mathrm{Na}$ +80 mM TMA. $C, I_{\mathrm{Na}}$ tail currents at the indicated voltages following a 0.5 msec activating pulse to $-10 \mathrm{mV}$ (see inset). GFL cell OC086E (not TTXsubtracted; $78 \mathrm{pF}, 0.94 \mathrm{M} \Omega, 10.5^{\circ} \mathrm{C}, 6$ d). $D$, Values of time constants fitted to TTX-sensitive $I_{\mathrm{Na}}$ tails plotted versus voltage for $2 \mathrm{GFL}$ cells (flled symbols) and a single giant axon studied in both $100 \mathrm{~mm} \mathrm{Ca} \mathrm{(O)} \mathrm{and} 20 \mathrm{~mm} \mathrm{Ca}(\Delta)$. GFL cells: (○) OC086J (cf. Fig. 4), (А) MAY 12B (ct. Fig. 6), ( $\star$ ) OCO86E (cf. part $C$ ). Giant axon: JN153H.TLS perfused with $120 \mathrm{~mm} \mathrm{Na}+20$ or $100 \mathrm{~mm}$ $\mathrm{Ca}$ externally and internally with 200 mM TMA. 


\section{A}

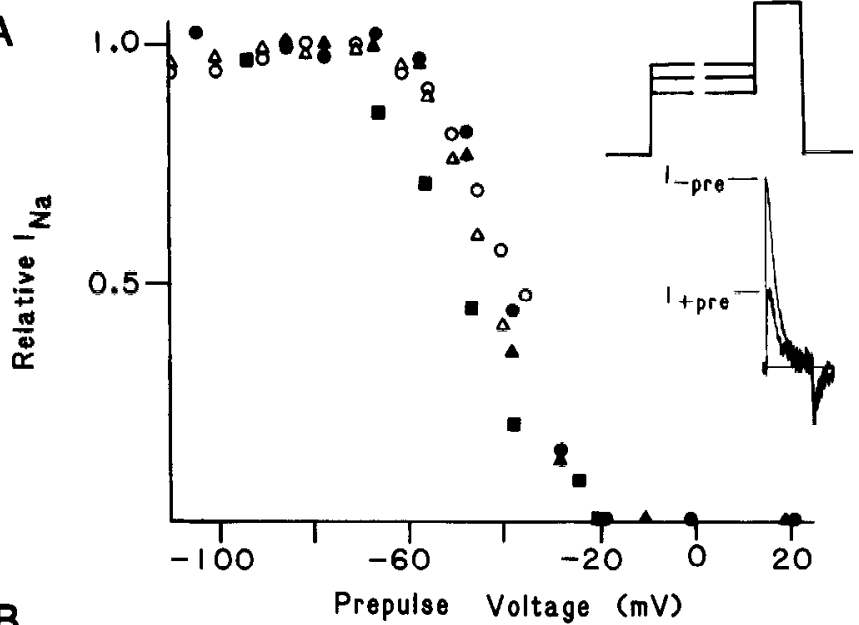

B

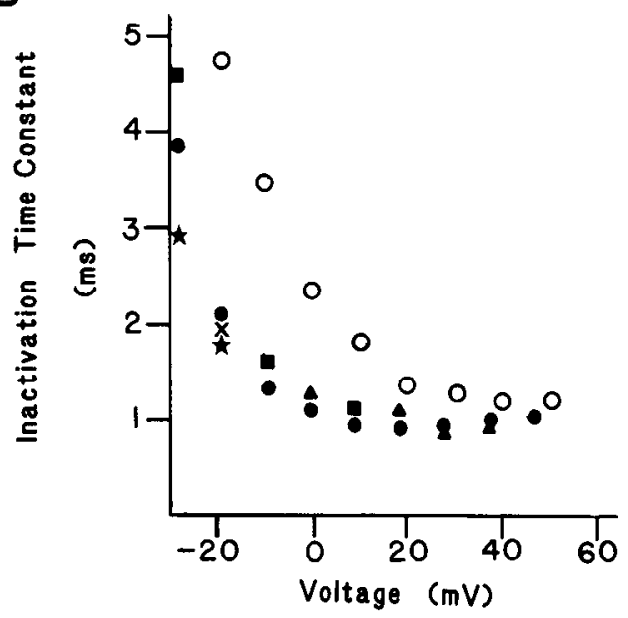

Figure 9. Inactivation of prepulse-sensitive $I_{\mathrm{Na}}$ in GFL cells versus giant axon. $A$, Prepulse-sensitive $I_{\mathrm{Na}}$ was determined as described in text and as shown in the inset. The relative amount of $I_{\mathrm{Na}}$ available to open during a large test pulse is plotted versus prepulse voltage in a standard way. GFL cells: (A) MAY8A (28 pF, $\left.1.2 \mathrm{M} \Omega, 10^{\circ} \mathrm{C}, 10 \mathrm{~d}\right),(\mathbf{0})$ MAY8B (32 pF, $\left.1.2 \mathrm{M} \Omega, 10^{\circ} \mathrm{C}, 10 \mathrm{~d}\right),(\square)$ NO216A $(67 \mathrm{pF}, 0.8 \mathrm{M} \Omega$, $\left.10^{\circ} \mathrm{C}, 7 \mathrm{~d}\right)$. Giant axons: $(O)$ SE055A.TLS and $(\triangle)$ SE055B.TLS, both perfused externally with $120 \mathrm{~mm} \mathrm{Na}+50 \mathrm{~mm} \mathrm{Ca}$ and internally with $200 \mathrm{~mm}$ TMA. $B$, Time constant of inactivation is plotted versus voltage from 3 GFL cells (filled symbols) and one giant axon (open circles). GFL

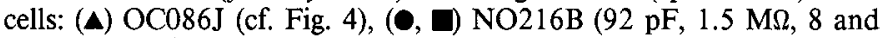
$\left.10^{\circ} \mathrm{C}, 7 \mathrm{~d}\right),(\star, \mathrm{X}) \mathrm{AP} 227 \mathrm{~A}\left(89 \mathrm{pF}, 2.2 \mathrm{M} \Omega, 10^{\circ} \mathrm{C}, 6 \mathrm{~d}\right)$. See text for details. Giant axon data is replotted from Figure 5 of Bezanilla and Armstrong (1977).

voltages, $\mathrm{Cd}$ is evidently a weaker blocker of outward current than of inward current through these channels (compare Fig. $14, C$ and $E$ ). This property would lead to a $C d$-induced "outward" rectification in the noninactivating $I_{\mathrm{Na}}-V$ curve around the reversal potential.

\section{Discussion}

"Normal" inactivating Na channels in soma versus axon

One major result of this paper is that most $\mathrm{Na}$ channels inappropriately expressed in vitro by axotomized GFL somata are practically indistinguishable from their appropriately expressed counterparts in the giant axons formed by these neurons in vivo. Voltage dependence of activation, kinetics of activation, and voltage dependence of inactivation are essentially equivalent in the 2 sets of data described here. Minor differences noted with
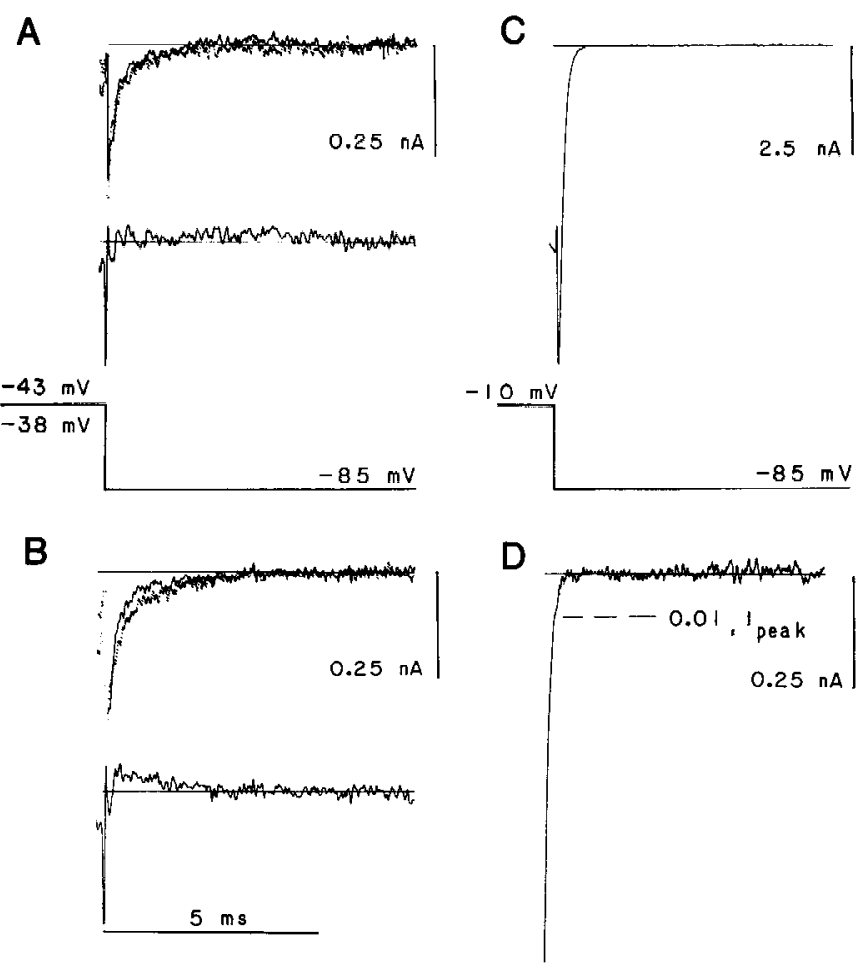

Figure 10. Lack of threshold Na channcls in GFL cclls. A, Upper panel shows inward tail currents recorded at $-85 \mathrm{mV}$ following a depolarization to $-43 \mathrm{mV}$ in the absence (solid trace) and presence (dotted trace) of 100 nM TTX. The difference between these traces, obtained by direct subtraction, is shown in the lower panel. $B$, Results analogous to those in $A$ obtained for a depolarization to $-38 \mathrm{mV}$. $C$, TTX-sensitive $I_{\mathrm{Na}}$ tail following a $1 \mathrm{msec}$ pulse to $-10 \mathrm{mV} . D$, Tenfold amplification of the final approach of the $I_{\mathrm{Na}}$ tail from $C$ to the baseline. The dashed line $\left(0.01 I_{\text {neak }}\right)$ indicates the amplitude corresponding to $1 \%$ of the peak $I_{\mathrm{Na}}$ tail amplitude measured in C. GFL cell OC086J (cf. Fig. 4).

regard to these parameters probably reflect the slightly different experimental conditions employed (e.g., Ca concentration of external solutions or ionic strength of internal solution) or the difference in squid species utilized (Loligo opalescens vs pealei).

The only obviously significant difference between inactivating $\mathrm{Na}$ channels in GFL cells and in axons concerns the kinetics of inactivation. Although the time constant of inactivation at very positive voltages is identical in GFL cells and axons, inactivation in GFL cells is much faster at less positive voltages. Between 0 and $-20 \mathrm{mV}$, for example, $I_{\mathrm{Na}}$ in GFL cells would inactivate more than twice as quickly as in the giant axon (Fig. $9 B$ ). The rate of inactivation in intact giant axons (i.e., not internally perfused) is accelerated by low external Ca levels in this voltage range (Shoukimas, 1978), but this effect was not demonstrated in our control experiment of comparing $10 \mathrm{~mm}$ $\mathrm{Ca}$ with $50 \mathrm{~mm} \mathrm{Ca}$ with a GFL cell.

In this case, additional experiments on GFL cell bodies in $L$. pealei or on giant axons in $L$. opalescens are desirable. From the only published record of TTX-sensitive $I_{\mathrm{Na}}$ in a GFL cell from $L$. pealei (fig. 3 of Llano and Bookman, 1986), an inactivation time constant of $3 \mathrm{msec}$ at $-10 \mathrm{mV}$ can be estimated, a value similar to the axonal data from $L$. pealei in Figure $9 B$. Thus, the GFL cell versus axon data in Figure $9 B$ may reflect a genuine species difference.

The unusually rapid inactivation kinetics in GFL cell bodies of $L$. opalescens nonetheless presents a natural experiment for 
A

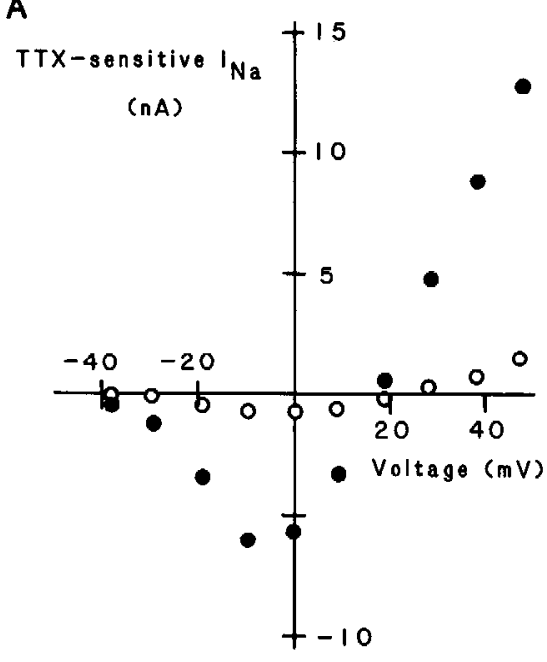

B

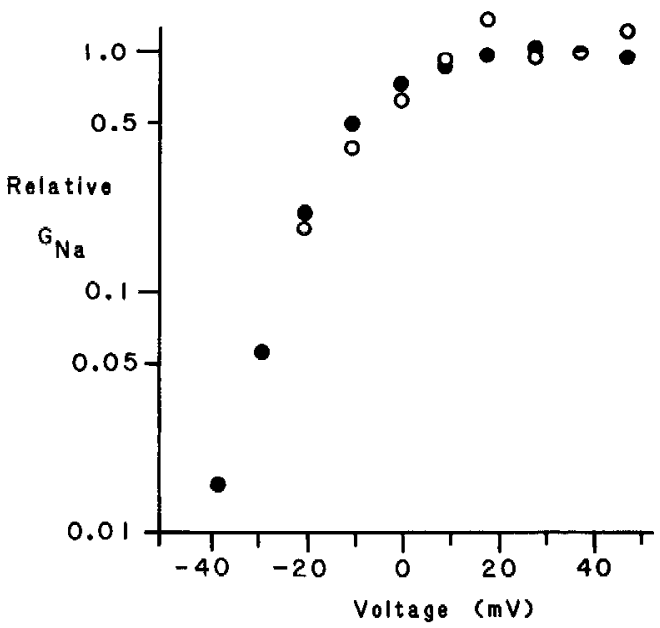

Figure 11. Voltage dependence of the TTX-sensitive, inactivation-resistant $G_{\mathrm{Na}}$ in GFL cells. $A, I_{\mathrm{Na}}-V$ curves for peak $I_{\mathrm{Na}}(\boldsymbol{\bullet}$, measured with no prepulse) and for prepulse-resistant $I_{\mathrm{Na}}(\mathrm{O}$, measured at the end of a 5 msec activating pulse). Data is from the records displayed in Figure 4. $B, G_{\mathrm{Na}}-V$ curves for peak $I_{\mathrm{Na}}(\odot)$ and prepulse-resistant $I_{\mathrm{V} \mathrm{Va}}$ (O) derived from data in $A$. testing the general applicability of recent models of inactivation developed for mammalian neuroblastoma cells (Aldrich et al., 1983; Aldrich and Stevens, 1987; Gonoi and Hille, 1987). Some of these models have been problematic to reconcile with giant axon data from L. pealei (Armstrong and Bezanilla, 1977; Bezanilla and Armstrong, 1977). The comparatively much faster rate of inactivation (relative to activation) in $L$. opalescens GFL cells than in axons of $L$. peale $i$ should expedite analysis of this question (cf. Aldrich, 1986).

\section{Noninactivating Na channels in soma versus axon}

A second important result of this study is that not all Na channels that are inappropriately expressed in vitro are the same, at least from the functional point of view. The fraction of noninactivating $G_{\mathrm{Na}}$ identified in GFL somata is in many ways indistinguishable from the normally inactivating $G_{\mathrm{Na}}$ discussed above. The voltage dependence of activation, activation/deactivation kinetics, reversal potential, and sensitivity to TTX and STX are similar enough in the 2 types of $G_{\mathrm{Na}}$ to be considered indistinguishable. Aside from the apparent total lack of prepulse-induced inactivation, this second-type of TTX-sensitive $G_{\mathrm{Na}}$ is distinguished by a high degree of sensitivity to block by $\mathrm{Cd}$ ions in the external solution. These are major functional differences that would ordinarily justify identifying the 2 types of $G_{\mathrm{Na}}$ as representing 2 different channel types.

One question concerning the noninaclivating $G_{\mathrm{Na}}$ in GFL cells is whether it is unique to the somata of these giant neurons, because a sizeable fraction of TTX-sensitive $G_{\mathrm{Na}}$ that does not rapidly inactivate also exists in perfused axons. This noninactivating $G_{\mathrm{Na}}$ was first described by Chandler and Meves (1970), has since been noted and studied in many reports, and is still not completely understood. Chandler and Meves (1970) postulated that the noninactivating $G_{\mathrm{Na}}$ was due to a second open state of the normal $\mathrm{Na}$ channels, but they could not rule out the possibility of a completely different second type of axonal $\mathrm{Na}$ channel with unusual properties. Na channel subtypes are now well known, and more recently, Matteson and Armstrong (1982) concluded that a second type of "sleepy" $\mathrm{Na}$ channel does, in fact, exist and give rise to the noninactivating $G_{\mathrm{Na}}$ in giant axons. The sleepy fraction of $\mathrm{Na}$ channels was also postulated to be in a very slow kinetic equilibrium with normal channels so that interconversion of the 2 types could occur. Other studies have indicated that the apparent amount of noninactivating axonal $G_{\mathrm{Na}}$ can be influenced to a large degree by the species of impermeant monovalent cations used in the internal perfusate (Oxford and Yeh, 1985) and by pharmacological manipulations (Yeh and Oxford, 1985). These latter workers interpret these

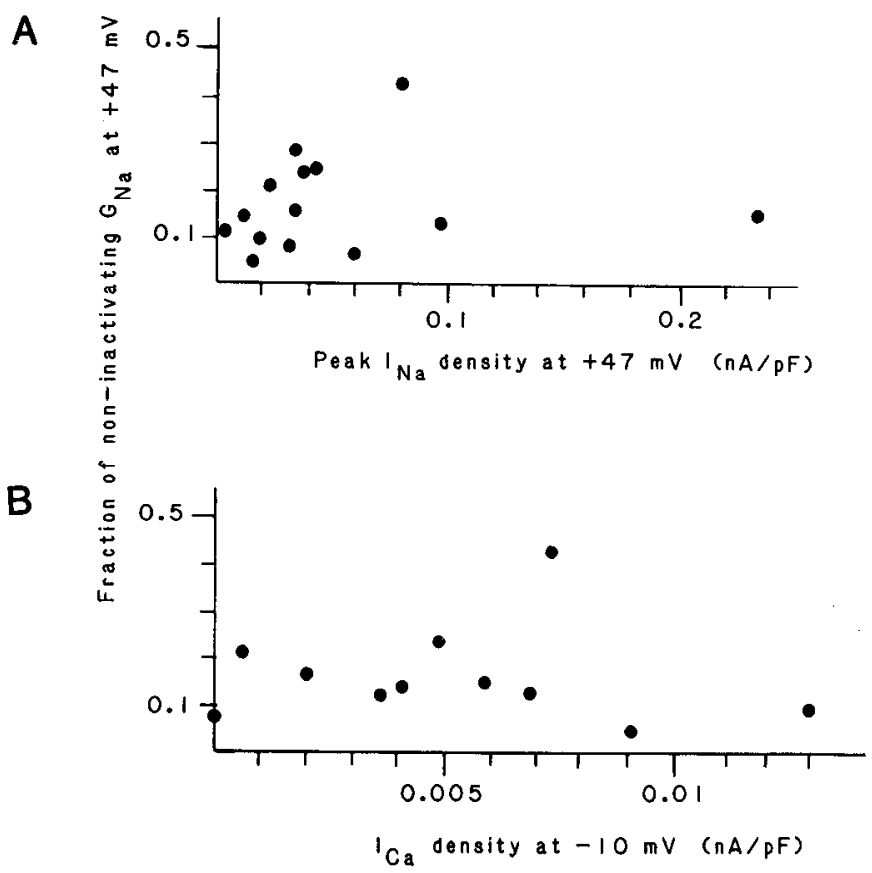

Figure 12. Sensitivity of inactivating and noninactivating $G_{\mathrm{Na}}$ to block by TTX and STX. $A, I_{\mathrm{Na}}$ recorded at $+47 \mathrm{mV}$ in the absence $(0)$ and presence $(10)$ of $10 \mathrm{nM}$ TTX. Both peak $I_{\mathrm{Na}}$ and steady-state $I_{\mathrm{Na}}$ are equally reduced by TTX. $B$, Prepulse-resistant $I_{\mathrm{Na}}(50 \mathrm{msec}$ prepulse to $-38 \mathrm{mV}$ ) recorded at $+47 \mathrm{mV}$ with $(10)$ and without (0) $10 \mathrm{nM}$ TTX. $C, I_{\mathrm{Na}}$ recorded at $+47 \mathrm{mV}$ in the presence of 0,10 , and $100 \mathrm{~nm}$ STX. $D$, Difference records obtained by subtraction of the traces in $C$ for $0-10$ nM STX and 10-100 nM STX. $E$, Comparison of the 10-100 nм STX trace from $C$ with the $0-10$ nM STX trace after scaling the latter by a factor of 2.78 . GFL cells: $(A, B) \operatorname{SE} 246 \mathrm{~V}\left(133 \mathrm{pF}, 1.0 \mathrm{M} \Omega, 11^{\circ} \mathrm{C}, 4 \mathrm{~d}\right)$ and $(C-E)$ OC046C $\left(112 \mathrm{pF}, 0.9 \mathrm{M} \Omega, 11^{\circ} \mathrm{C}, 3 \mathrm{~d}\right)$. 

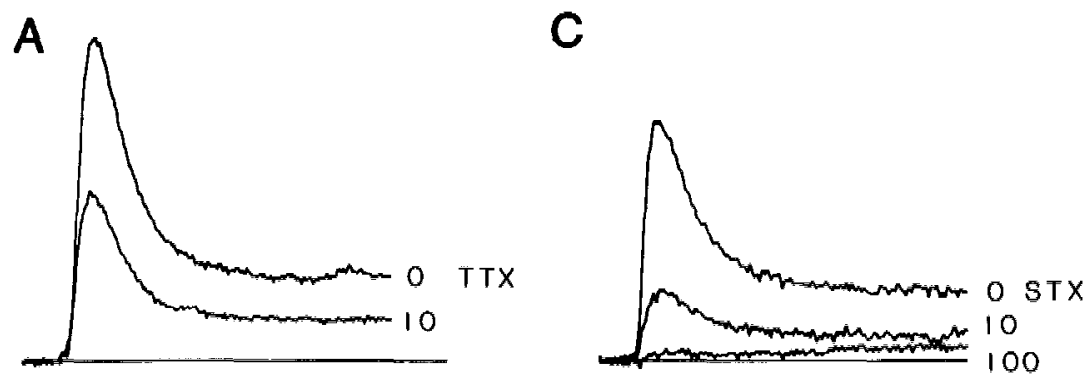

Figure 13. Correlations of the fraction of noninactivating $G_{\mathrm{Na}}$ with the density of peak $I_{\mathrm{Na}}(A)$ and $I_{\mathrm{Ca}}(B)$. Amount of noninactivating, TTX-sensitive $I_{\mathrm{Na}}$ at $+47 \mathrm{mV}$ relative to peak $I_{\mathrm{Na}}$ was estimated from either prepulse-resistant $I_{\mathrm{Na}}$ or from steady-state $I_{\mathrm{Na}}$ at the end of a 5 msec activating pulse. $I_{\mathrm{C}}$ was taken as the inward current at $-10 \mathrm{mV}$ (5 msec activating pulse) which was resistant to $100 \mathrm{nM}$ TTX.

\section{B}

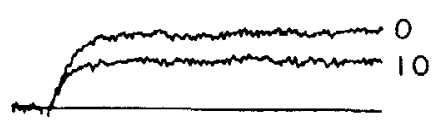

$5 \mathrm{~ms}$

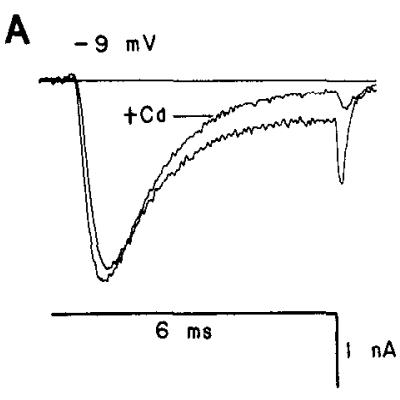

B

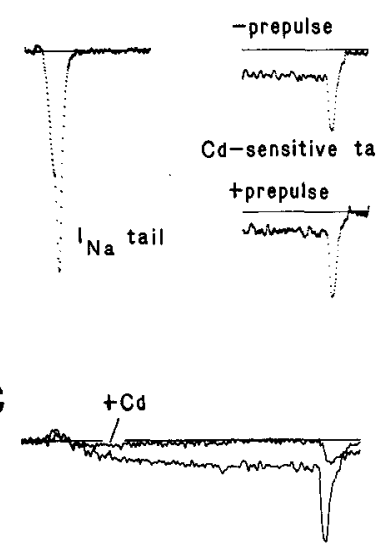

D

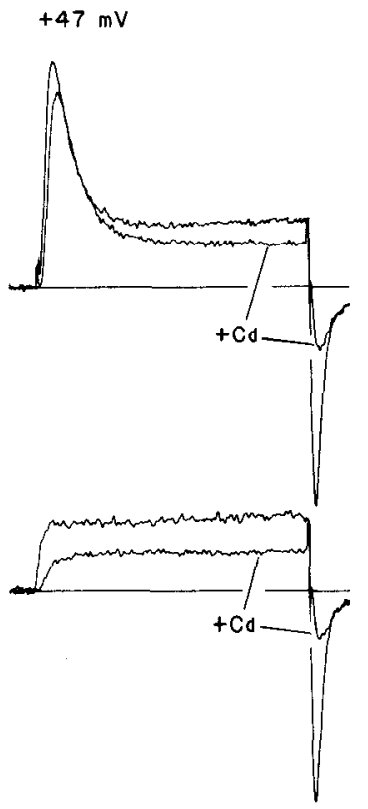

F

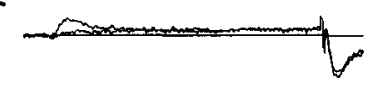

Figure 14. Sensitivity of noninactivating, TTX-sensitive $I_{\mathrm{Na}}$ to block by Cd. $A$, Current recorded at $-9 \mathrm{mV}$ in the presence (+Cd) and absence of $2 \mathrm{mM} \mathrm{CdCl}_{2} . B$, The $\mathrm{Cd}$-sensitive tail current from $A$ is plotted (-prepulse). The $I_{\mathrm{Na}}$ tail following a $0.5 \mathrm{msec}$ pulse to $+9 \mathrm{mV}$ is plotted on the left side of the figure for comparison. $C$, Prepulse-resistant currents are shown at $-9 \mathrm{mV}(50 \mathrm{msec}$ prepulse to $-38 \mathrm{mV})$ in the presence $(+\mathrm{Cd})$ and absence of $2 \mathrm{mM} \mathrm{CdCl}_{2}$. Cd blocks the inward current during and after the pulse; the Cd-sensitive tail is plotted in $B . D$ and $E$, Results analogous to those in $A$ and $C$ but obtained at $+47 \mathrm{mV}$. $F$, Currents accompanying the samc pulses as in $E$ but after adding $100 \mathrm{nM}$ STX to the bath. GFL cell SE246Z (145 pF, $\left.0.47 \mathrm{M} \Omega, 11^{\circ} \mathrm{C}, 4 \mathrm{~d}\right)$.

D

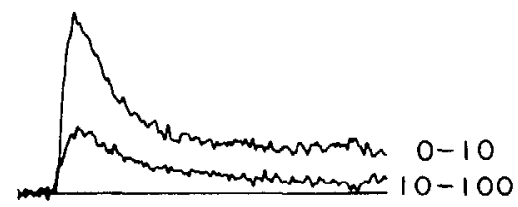

$E$

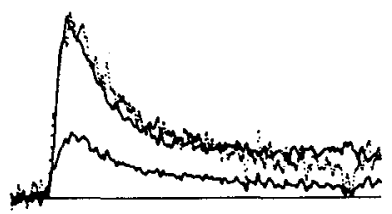

effects as modulation of the inactivation mechanism of normal $\mathrm{Na}$ channcls.

Although the basis for noninactivating $G_{\mathrm{Na}}$ in the giant axon is not completely understood, it is unlikely that this fraction of $G_{\mathrm{Na}}$ is identical to that in cultured GFL cell bodies. The most obvious difference is the fact that the noninactivating axonal $G_{\mathrm{Na}}$ has a different voltage dependence than that for the normally inactivating $G_{\mathrm{Na}}$. This is a finding common to all studies cited above, and contrary to our results on GFL somata.

This conclusion must be qualified slightly, however. Sensitivity of the noninactivating axonal channels to block by divalent cations is not known, and preferential block of inward $I_{\mathrm{Na}}$ by $\mathrm{Ca}$ (relative to outward $I_{\mathrm{Na}}$ ) through the noninactivating axonal channels could influence their apparent voltage dependence. This effect is produced on the noninactivating $G_{\mathrm{Na}}$ in cultured GFL somata by $\mathrm{Cd}$ ions, and a similar voltage-dependent block of inactivating axonal $\mathrm{Na}$ channels occurs with $\mathrm{Ca}$ (Taylor et al., 1976), Zn (Gilly and Armstrong, 1982), Cd, and other divalent cations (Tanguy and Yeh, 1988).

Divalent cation block is undoubtedly a property of many, and perhaps all, $\mathrm{Na}$ channels, and it can serve as a useful diagnostic feature of channel type. For example, TTX-insensitive $I_{\mathrm{Na}}$ in cultured mammalian neurons can be blocked by Cd (Ikeda and Schofield, 1987; Jones, 1987), and, as with the noninactivating $G_{\mathrm{Na}}$ in GFL somata, inward current appears to be preferentially blocked.

The most straightforward interpretation of our data on noninactivating $G_{\mathrm{Na}}$ in cultured GFL cells is that it is due to the presence of a small fraction of inappropriately expressed $\mathrm{Na}$ channels that are identical to the channels making up the bulk of the population except that they lack the inactivation mechanism and have an additional modification resulting in an abnormally high sensitivity to block by $\mathrm{Cd}$, and possibly other divalent cations.

How the 2 forms of $\mathrm{Na}$ channels in GFL cells are related 
molecularly is presently unknown, but they need not represent products of distinct genes. Although the molecular basis of inactivation is not understood (Agnew et al., 1988), the underlying mechanism is relatively labile, being susceptible to proteolysis from the internal surface of the axonal membrane (Armstrong et al., 1973; Rojas and Rudy, 1976). If such modification occurred naturally, e.g., via endogenous intracellular proteases, a population of $\mathrm{Na}$ channels could result that lacks inactivation but is otherwise basically normal. Such proteases might be unusually active in vitro, especially in the case of GFL cells, where $\mathrm{Na}$ channel expression is clearly inappropriate. Alternatively, errors in processing (and potentially assembly) of $\mathrm{Na}$ channels might produce the noninactivating $\mathrm{Na}$ channels we find in cultured GFL cells. The high sensitivity to block by $\mathrm{Cd}$ ions we observe for these channels might occur secondarily due to the destruction of inactivation, or it could result from a separate modification of the conducting pore. Whether such endogenous modification of functional $\mathrm{Na}$ channels really occurs, either in vitro or in vivo, and what is the nature of cellular control processes operative in GFL cells and giant axons are outstanding questions. Careful analysis of $\mathrm{Na}$ channel variants in a welldefined in vitro system will be important in providing answers.

The most fundamental finding in this paper is that axotomized GFL cell bodies express voltage-controlled, TTX-sensitive $\mathrm{Na}$ channels that have been synthesized and processed in the soma alone to a functional state of perfection identical to that shown by the channels normally found only in the giant axon. This is true for $85 \%$ of the channels (i.e., the inactivating population) on the average, and the axotomized GFL cell preparation should be valuable for single-channel recordings. Because $\mathrm{Na}$ channels are inappropriately inserted into the soma membrane in vitro, however, rather than being selectively targeted for insertion into axonal membrane as occurs in vivo, the preparation also shows promise for cell biological studies. Whether sorting of $\mathrm{Na}$ channels continues in vitro and whether channels are inserted into specialized regions of the cultured GFL cells, e.g., at the site of the old axon hillock or at the tips of regenerating axons, are questions currently under investigation.

\section{References}

Agnew, W. S., E. C. Cooper, W. M. James, S. A. Tomiko, R. L. Rosenberg, M. C. Emerick, A. M. Correa, and J. Y. Zhou. (1988) Voltage-sensitive $\mathrm{Na}$ channels: Molecular structure and function. In $\mathrm{Mo}$ lecular Biology of Ion Channels, W. S. Agnew, T. Claudio, and F. S. Sigworth, eds., Academic, New York (in press).

Aldrich, R. W. (1986) Voltage-dependent gating of sodium channels: Towards an integrated approach. Trends. Neurosci. 9: 82-86.

Aldrich, R. W., and C. F. Stevens (1987) Voltage-dependent gating of single sodium channels from mammalian neuroblastoma cells. J. Neurosci. 7: 418-431.

Aldrich, R. W., D. P. Corey, and C. F. Stevens (1983) A reinterpretation of mammalian sodium channel gating based on single channel recording. Nature 306: 436-441.

Armstrong, C. M., and F. Bezanilla (1977) Inactivation of the sodium channel. II. Gating current experiments. J. Gen. Physiol. 70: 567590.

Armstrong, C. M., and W. F. Gilly (1979) Fast and slow steps in the activation of sodium channels. J. Gen. Physiol. 74: 691-711.

Armstrong, C. M., and D. R. Matteson (1984) Sequential models of sodium channel gating. Curr. Top. Membr. Transp. 22: 331-352.

Armstrong, C. M., F. Bezanilla, and E. Rojas (1973) Destruction of sodium conductance inactivation in squid axons perfused with pronase. J. Gen. Physiol. 62: 375-391.

Barchi, R. L. (1987) Sodium channel diversity: Subtle variations on a complex theme. Trends. Neurosci. 10: 221-223.
Barchi, R. L. (1988) Probing the molecular structure of the voltagedependent sodium channel. Annu. Rev. Neurosci. 11: 455-495.

Bezanilla, F., and C. M. Armstrong (1977) Inactivation of the sodium channel. I. Sodium current experiments. J. Gen. Physiol. 70: 549566 .

Brismar, T., and W. F. Gilly (1987) Synthesis of sodium channels in the cell bodies of squid giant axons. Proc. Natl, Acad. Sci. USA 84: 1459-1463.

Chandler, W. K., and H. Meves (1970) Fvidence for two types of sodium conductance in axons perfused with sodium fluoride solution. J. Physiol. (Lond.) 211: 653-678.

Chow, R. H., and C. M. Armstrong (1988) Cadmium block of calcium currents in squid neurons. Biophys. J. 53: 554a.

Cooper, E. C., S. A. Tomiko, and W. S. Agnew (1987) Reconstituted vollage-sensitive sodium channel from Electrophorus electricus: Chemical modifications that alter regulationof ion permeability. Proc. Natl. Acad. Sci. USA 84: 6282-6286.

French, R. J., and R. Horn (1983) Sodium channel gating: Models, mimics, and modifiers. Annu. Rev. Biophys. Bioeng. 12: 319-356.

Gilly, W. F., and C. M. Armstrong (1982) Slowing of sodium channel opening kinetics in squid axon by extracellular zinc. J. Gen. Physiol. 79: 936-964.

Gilly, W. F., and C. M. Armstrong (1984) Threshold channels-A novel type of sodium channel in squid giant axon. Nature 309: 448450.

Goldin, A. L., T. Snutch, H. Lubbert, A. Dowsett, J. Marshall, V. Auld, W. Downey, L. C. Fritz, H. A. Lester, R. Dunn, W. A. Catterall, and N. Davidson (1986) Messenger RNA coding for only the alpha subunit of the rat brain $\mathrm{Na}$ channel is sufficient for expression of functional channels in Xenopus oocytes. Proc. Natl. Acad. Sci. USA 83: 7503-7507.

Gonoi, T., and B. Hille (1987) Gating of $\mathrm{Na}$ channels. Inactivation modifiers discriminate among models. J. Gen. Physiol. 89: 253-274.

Gordon, D., D. Merrick, V. Auld, R. Dunn, A. L. Goldin, N. Davidson, and W. A. Catterall (1987) Tissue-specific expression of the $R_{I}$ and $\mathrm{R}_{\mathrm{II}}$ sodium channel subtypes. Proc. Natl. Acad. Sci. USA 84: $8682-$ 8686 .

Hodgkin, A. L., and A. F. Huxley (1952) A quantitative description of membrane current and its applications to conduction and excitation in nerve. J. Physiol. (Lond.) 117: 500-544.

Huguenard, J., O. P. Hamill, and D. A. Prince (1988) Developmental changes in $\mathrm{Na}^{+}$conductances in rat neocortical neurons: Appearance of a slowly inactivating component. J. Neurophysiol. 59: 778-795.

Ikeda, S. R., and G. G. Schofield (1987) Tetrodotoxin-resistant sodium current of rat nodose neurones: Monovalent cation selectivity and divalent cation block. J. Physiol. (Lond.) 389: 255-270.

Jones, S. W. (1987) Sodium currents in dissociated bull-frog sympathetic neurones. J. Physiol. (Lond.) 389: 605-627.

Krafte, D. S., T. P. Snutch, J. P. Leonard, N. Davidson, and H. A. Lester (1988) Evidence for the involvement of more than one mRNA species in controlling the inactivation process of rat and rabbit brain $\mathrm{Na}$ channels expressed in Xenopus oocytes. J. Neurosci. 8: 28592868.

Llano, I., and R. J. Bookman (1986) Ionic conductances of squid giant fiber lobe neurons. J. Gen. Physiol. 88: 543-569.

MacDermott, A. B., and G. L. Westbrook (1986) Early development of voltage-dependent sodium currents in cultured mouse spinal cord neurons. Dev. Biol. 113: 317-326.

Mandel, G., S. S. Cooperman, R. A. Maue, R. H. Goodman, and P. Brehm (1988) Selective induction of brain type II Na channels by nerve growth factor. Proc. Natl. Acad. Sci. USA 85: 924-928.

Martin, R., and R. Miledi (1986) The form and dimension of the giant synapse of squids. Phil. Trans. R. Soc. London [Biol.] 312: 355-377.

Matteson, D. R., and C. M. Armstrong (1982) Evidence for a population of sleepy sodium channels in squid axon at low temperature. J. Gen. Physiol. 79: 739-758.

Miledi, R. (1967) Spontaneous synaptic potentials and quantal release of transmitter in the stellate ganglion of the squid. J. Physiol. (Lond.) 192: 379-406.

Noda, M., I. Takayuk, T. Kayano, H. Suzuki, H. Takeshima, M. Kurasaki, H. Takahashi, and S. Numa (1986a) Existence of distinct sodium channel messenger RNAs in rat brain. Nature 320: 188-192.

Noda, M., T. Ikeda, H. Suzuki, H. Takeshima, T. Takahashi, M. Kuno, and S. Numa (1986b) Expression of functional sođium channels from cloned cDNA. Nature 322: 826-828. 
Oxford, G. S. (1981) Some kinetic and steady-state properties of sodium channels after removal of inactivation. J. Gen. Physiol. 77: 122.

Oxford, G. S., and J. Z. Yeh (1985) Interactions of monovalent cations with sodium channels in squid axon. I. Modification of physiological inactivation gating. J. Gen. Physiol. 85: 583-602.

Rojas, E., and B. Rudy (1976) Destruction of the sodium conductance inactivation by a specific protease in perfused nerve fibres from $\mathrm{Lo}$ ligo. J. Physiol. (Lond.) 262: 501-531.

Rudy, B., B. Kirschenbau, A. Rukenstein, and L. A. Greene (1987) Nerve growth factor increases the number of functional Na channels and induces TTX-resistant $\mathrm{Na}$ channels in $\mathrm{PCl} 2$ phaeochromocytonma cells. J. Neurosci. 7: 1613-1625.

Schmidt, J. W., and W. A. Catterall (1986) Biosynthesis and processing of the alpha subunit of the voltage-sensitive sodium channel in rat brain neurons. Cell 46: 437-445.

Schmidt, J. W., and W. A. Catterall (1987) Palmitylation, sulfation, and glycosylation of the alpha subunit of the sodium channel. J. Biol. Chem. 262: 13713-13723.

Schmidt, J., S. Rossie, and W. A. Catterall (1985) A large intracellular pool of inactive Na channels in developing rat brain. Proc. Natl. Acad. Sci. USA 82: 4847-4851.
Shoukimas, J. J. (1978) Effect of calcium upon sodium inactivation in the giant axon of Loligo pealei. J. Membr. Biol. 38: 271-289.

Tanguy, J., and J. Z. Yeh (1988) Divalent cation block of normal and BTX-modified sodium channels in squid axons. Biophys. J. 53: 229a. Taylor, R. E., C. M. Armstrong, and F. Bezanilla (1976) Block of sodium channels by external calcium ions. Biophys. J. 16: 27a.

Thornhill, W. B., and S. R. Levinson (1987) Biosynthesis of electroplax sodium channels in Electrophorus electrocytes and Xenopus oocytes. Biochemistry $26: 4381-4388$.

Wollner, D. A., and W. A. Catterall (1986) Localization of sodium channels in axon hillocks and initial segments of retinal ganglion cells. Proc. Natl. Acad. Sci. USA 83: 8424-8428.

Yeh, J. Z., and G. S. Oxford (1985) Interactions of monovalent cations with sodium channels in squid axon. II. Modification of pharmacological inactivation gating. J. Gen. Physiol. 85: 603-620.

Young, J. Z. (1938) The functioning of the giant nerve fibres of the squid. J. Exp. Biol. 15: 170-185.

Young, I. Z. (1939) Fused neurones and synaptic contacts in the giant nerve fibres of cephalopods. Phil. Trans. R. Soc. London [Biol.] 229; $465-503$. 